\title{
THE RISK IS IN THE DETAIL: HISTORICAL CARTOGRAPHY AND A HERMENEUTIC ANALYSIS OF HISTORICAL FLOODS IN THE CITY OF MURCIA
}

\author{
SALVADOR GIL-GUIRADO ${ }^{1,2 *}$, JORGE OLCINA CANTOS ${ }^{2,3}$, \\ ALFREDO PÉREZ-MORALES ${ }^{1}$, MARIANO BARRIENDOS ${ }^{4}$ \\ ${ }^{1}$ Department of Geography, University of Murcia, Campus de la Merced, 30001 Murcia, Spain. \\ ${ }^{2}$ Laboratory of Climatology, Interuniversity Institute of Geography, University of Alicante, \\ San Vicente del Raspeig, 03690 Alicante, Spain. \\ ${ }^{3}$ Department of Regional Geographic Analysis and Physical Geography, University of Alicante, \\ Sant Vicent del Raspeig, 03690 Alicante, Spain. \\ ${ }^{4}$ Department of History and Archaeology, University of Barcelona, \\ Montalegre 6, 08001 Barcelona, Spain.
}

\begin{abstract}
The study of historical floods is a growing research trend that has generated numerous methodologies that aim to convert the qualitative historical documentation into quantitative information. This codification process aims to make comparable in time and space the manner in which past societies adapted to floods, and so extract the positive or negative points that can help reduce vulnerability and increase the resilience of current societies. However, the diversity of cultural and historical contexts, as well as the spatial-temporal heterogeneity of documentary sources, makes it difficult to extrapolate quantitative methods in historical climatology. This situation means that interpretative analyses of texts are still necessary as a complement to quantitative studies. In this paper, we make a hermeneutic analysis of the three most catastrophic floods that have occurred in the city of Murcia (south-eastern Spain) in the last 400 years. We complete this analysis with a historical cartographic reconstruction of a quantitative nature. Among the main conclusions, we highlight the fact that the society of Murcia had strategies to overcome catastrophes that included the whole of society and an integrated emergency management. However, the state of poverty of privation prior to a flood is a determining factor in explaining the resilience of a social system. A large increase in exposure of flood-prone areas over the past two centuries is noteworthy but unsurprising. However, it is surprising that the percentage of urban area exposed to flooding is now smaller than in the past. Therefore, if we consider hazard avoidance as a form of management, we can say that pre-industrial Murcian society was less efficient in using the mechanisms available to adapt to flooding.
\end{abstract}

\section{El riesgo está en los detalles: cartografía histórica y análisis hermenéutico de las inundaciones históricas en la ciudad de Murcia.}

RESUMEN. El estudio de inundaciones históricas es una corriente investigadora al alza que ha generado numerosas metodologías que persiguen transformar la información cualitativa contenida en la documentación histórica, en información cuantitativa. Este proceso de codificación persigue hacer comparable en el tiempo y en el espacio la forma en que las sociedades se adaptaban a las inundaciones en el pasado, con el fin de extraer los puntos positivos o negativos que pueden ayudar a reducir la vulnerabilidad y aumentar la resiliencia de las sociedades actuales. Sin embargo, la diversidad de los contextos culturales e históricos, así como la heterogeneidad espaciotemporal del material documental, dificulta la capacidad de extrapolación de los métodos cuantitativos en climatología histórica. Esta situación, repercute en que sigan siendo necesarios los análisis hermenéuticos de 
textos, como complemento a los estudios de carácter cuantitativo. En este trabajo realizamos un análisis hermenéutico de las tres inundaciones más catastróficas ocurridas en la ciudad de Murcia (Sureste de España) en los últimos 400 años. Completamos este análisis con una reconstrucción cartográfica histórica de carácter cuantitativo. Entre las principales conclusiones destaca el hecho de que la sociedad murciana tenía estrategias de superación de catástrofes que involucraban al conjunto de la sociedad y que preconizaban una gestión integral de las emergencias. No obstante, el estado de penuria previo a una inundación es un factor determinante para explicar la capacidad de resiliencia del sistema social. En cuanto a la forma de exponerse al peligro, es destacable el gran aumento de la exposición a zonas inundables producido en los últimos dos siglos. Esto no es algo sorprendente, pero si lo es el hecho de que en el pasado el porcentaje de superficie urbana expuesta sobre el total fuera superior, comparando con la situación actual. Por lo tanto, si consideramos la evasión del peligro, como una forma de gestión, podemos afirmar que la sociedad murciana preindustrial usaba de forma menos eficiente los mecanismos de los que disponía para adaptarse a las inundaciones.

Key words: Hermeneutic analysis, historical cartography, Huerta of Murcia, vulnerability, catastrophic floods.

Palabras clave: Análisis hermenéutico, cartografía histórica, Huerta de Murcia, vulnerabilidad, inundaciones catastróficas.

Received: 4 September 2020

Accepted: 7 February 2021

*Corresponding author: Salvador Gil-Guirado, Department of Geography, University of Murcia, Campus de la Merced, 30001 Murcia, Spain. Email address: salvador.gil1@um.es.

\section{Introduction}

The history of society vs environment relationships is a process of frictions and imbalances in the form of traumatic impacts. These imbalances can be understood as natural risks. However, the complexity and multi-dimensionality of the factors involved in risk processes have determined approaches to their study from historicist and/or positivist perspectives. This has created conceptual problems around the definition of natural risk. The term is therefore conceived differently by researchers depending on the paradigm they represent. While some propose natural risk as a mathematical product that can be modelled and measurable in units; others argue that, as a human creation, risks have no meaning outside the perceptual and social orbit. These two tendencies are evidenced through definitions of the concept of risk.

On the quantitative side, the definitions of natural risk focus on its quantifiable nature. Villevieille (1997) writes that risk is the mathematical product of the probability of a hazardous event occurring and the estimation of damage caused by such an event. Pita and Olcina Cantos (2000) describe risk as an extreme phenomenon that produces negative impacts on the environment and society, and which are the result of multiplying the value of the hazard by the damage caused (measured in monetary units). Dauphiné (2001) defines risk as the product of the dangerousness and vulnerability that occurs in a territory.

With regard to the socio-perceptual aspect, definitions that consider the underlying human character of risk processes stand out. Calvo García-Tornel (2001) points out that the measurement of risk is always human. Beck (2002) goes further by indicating the social character of risks and argues that risk is the modern approach to forecasting the consequences of human action. In this same line, Giddens (2003) stresses that risks are creations of our growing knowledge about the world. 
If we approve the postulates of the social aspect, we can confirm that risk processes show the characteristics of human behaviour that are poorly adapted to the natural environment, and so the natural component of natural risks simply plays an explanatory role in the development of a hazard event (Horacio et al., 2019). The aspect which should be emphasised is vulnerability - since a non-vulnerable system is not exposed to risk and is optimally protected from danger. In contrast, a highly vulnerable system makes any activity and any natural process a risky activity. This divergence explains the fact that when faced with the same natural phenomenon, numerous damages are produced in some places and no damages in other ones. Consequently, it is essential to act to reduce vulnerability to plan a territory and protect people, especially in a scenario in which the recurrence of extreme events seems to be increasing due to global warming (Grinsted et al., 2012). This is especially important for floods in the Mediterranean region (Blöschl et al., 2020), where the role of people as catalysts for flooding processes has also been significant in recent decades (Barredo, 2007).

We must consider other important associated concepts of hazard, vulnerability, and exposure. Hazard refers to natural processes that can damage society (Olcina Cantos, 2008). Vulnerability is the expected differential impact in terms of intrinsic characteristics (such as political conditions, cultural patterns, educational levels, and economic development) (López-Martínez et al., 2017). Finally, exposure is the amount of property susceptible to damage by a natural hazard (Pérez-Morales et al., 2018). The sum of these three factors is risk, to which we can add the intensity and duration of the catastrophic event (Olcina Cantos, 2008).

The concept of vulnerability is composite and multidimensional, as well as being subject to social and political interpretations - and so the approach taken varies depending on the position of the researchers. The concept can be discussed in ecological and environmental terms (Ollero, 2020), in relation to political economics, or as a reflection of social relations and class structure. However, any analysis of vulnerability must consider the social, economic, and organisational factors that influence differing levels of vulnerability among societies (Endfield, 2007). In line with this, Calvo García-Tornel (1997) states that vulnerability is the degree of effectiveness of a given social group in adapting its organisation to those changes in the natural environment that includes risk. Brooks et al. (2005) argue that vulnerability is represented by a set of socio-economic, political, and environmental variables that affect the sensitivity and exposure of populations to environmental threats, and consider risk as the level of possible deterioration caused by environmental events as measured by the sensitivity or vulnerability of the exposed systems. The factors that determine the level of vulnerability in this conception depend on environmental and social characteristics, the type of risk, as well as development aspects such as poverty, health status, inequality, and political factors.

The complexity of the interactions that determine vulnerability obligates to consider concepts such as resilience and adaptive capacity. Smit and Wandel (2006) discuss the strong interconnection of the concepts of adaptation, adaptive capacity, vulnerability, resilience, exposure, and sensitivity. The term adaptation as applied to natural hazards can be defined as the ability of groups or individuals to improve and add new methods to cope with environmental conditions based on their cultural repertoire (O’Brien and Holland, 1992). Adaptation strategies are key points, as they are manifestations of resilience (understood as the ability of a system to return to the situation prior to impact with the least possible damage), and therefore represent a way to reduce vulnerability (Smit and Wandel, 2006).

It seems clear that there is great heterogeneity in the definitions around natural risk, a heterogeneity that has to do both with the complexity and multidimensionality of the problem of natural risks, and with the epistemological approach of each researcher. In this respect, it is legitimate to think that this heterogeneity will be greater if the aim is to study natural risks from a historical perspective given that the economic, cultural, and social context is changing. Furthermore, the documentary sources which enable us to study natural risks in the past are not spatially or temporally homogeneous. Therefore, a hermeneutical approach in the study of historical risks continue to be essential to achieve a correct contemporaneity of the events that occurred (Glaser and Kahle, 2020). 
Despite being a recent development, historical studies are beginning to play an important role in the study of natural risk. Colten (1991) indicated that the reconstruction of a geographical progression plays an important role in current environmental litigation, partly because it enables a path to be followed in the management of crises, lessons learnt, and the evaluation of advances in knowledge of the factors generating vulnerability among human groups (and so facilitating an understanding of risk induction by societies). To show the most relevant aspects of social vulnerability, the most appropriate scale for this type of analysis is local. To improve the territorial management of risks, it is important to consider the variability of vulnerable populations to exposure to hazards (Cutter and Finch, 2007).

The power of comparison and replicability of a methodology is mainly based on its objectivity, and this is basically determined by the possibility of offering its results through numerical values (Brázdil et al., 2018). For the study of natural risks in a historical perspective, historical climatology has produced numerous methodologies for the reconstruction of natural disasters for different periods and locations. For example, Prieto and Rojas (2012; 2015) develop works on how water extremes have influenced some social processes in South America in recent centuries. Glaser et al. (2017) have done the same for Central Europe, Brázdil et al. (2019) for Northern Europe, and Pfister (2011) for Western Europe. To highlight only a few regions, Nash et al. (2019) explore the relationship between society and natural risk in southern Africa, Barriendos and Rodrigo (2006) for the Iberian Peninsula, and Endfield (2007) for colonial Mexico. Some works have explored the possibility of establishing quantitative methodologies through contextual analysis (Gil-Guirado et al., 2016, 2019; Glaser and Khale, 2020; Prieto and García Herrera, 2009; Diez-Herrero, 2020) with optimal results being obtained for regions with a common history and culture. However, all the previous works coincide in indicating that without a correct interpretation, the results remain unfocussed (Glaser et al., 2010) and therefore, it is impossible to make a real comparison of past results with the present.

The main methodological problems in historical risk studies refer to the heterogeneity of documentary sources that makes it difficult to establish unified methodologies (Nash et al., 2019). Cultural and religious divergences and socio-economic asymmetries also make difficult the comparison of regions and periods. However, despite the fact that the study of historical natural risks involves methodological difficulties and epistemological traps, there has been a certain unification of procedures in recent years. In particular, the brand of historical climatology has favored this unification of epistemological approaches with the common objective of learning from past natural disasters, regardless of the quantitative or interpretative approach employed. In conclusion, work on historical risks that aims to make considerations applicable today to improve the situation of people living in a territory must be based on the quantitative method, while at the same time reflecting on the hermeneutical nature of the interpretation of texts within social theory.

In this work we carry out a hermeneutic analysis of the historical information relating to the three major floods that affected the city of Murcia (southeastern Spain) in recent centuries. The San Calixto flood of 1651, the Nuestra Señora de los Reyes flood of 1733, and the Santa Teresa flood of 1879. In each of the centuries studied, these events were the greatest natural catastrophes caused by flood. The analysis of historical documentation shows numerous events and situations that helped or hindered the management of these disasters. From the quantitative point of view, we carried out a cartographic reconstruction thanks to the maps available from the beginning and end of the nineteenth century (Olcina y Diez, 2017). The aim of this cartographic reconstruction is to differentiate the effects of the floods in the nineteenth century from the current situation, both in absolute and relative terms. To do this, we digitised the available historical maps to establish the urban space in the nineteenth century and compare it with the urban space today. Finally, we digitised the perimeter of Murcia's medieval city wall and considered that its main role was to protect against flooding. We assigned a probable height to the wall based on archaeological work and using the height of the flood water for various return periods, and then we determined the type of flooding that the medieval wall could have withstood today. 
This cartographic analysis is new and enables the first quantitative comparison between the historical and current flood zones in the study area. A hermeneutic analysis, together with quantitative methodologies, enable us to establish the spatial, social, and historical reality of the floods in Murcia. The aim is to find out directly whether the trajectories of adaptation led to greater or lesser vulnerability and resilience to flood risk over time (Messerli et al., 2000).

\section{Sources and methodology}

Due to the intrinsic characteristics of flood risk and considering its instantaneous and perceptual magnitude, it is possible to speak of disasters or catastrophes in terms of greater or lesser affects (Olcina Cantos, 2008). The floods analysed in this work are considered disasters due to the number of deaths, the great social impact, and amount of destruction caused.

It is necessary to differentiate between two types of data sources: firstly, historical sources; and secondly, data sources of present time. Historical sources have been used for hermeneutic and historical mapping analysis, while data sources of present time have been used to analyse flood hazard and exposure as a basis for mapping analysis.

For the hermeneutic analysis of the flood of 14 October 1651 (San Calixto Flood); the flood of 6 September 1733 (Nuestra Señora de los Reyes Flood); and the flood of 14 October 1879 (Santa Teresa Flood), historical sources are used. The bulk of historical documentation corresponds to the Municipal Chapter Book (MCB). The MCB is an internal municipal document that textually collects all the decisions of the councillors and mayors who met regularly in municipal council meetings. This type of source is the best way to directly observe unfavourable climatic events (Perez Picazo et al., 1980). In this type of document, the extractable information focuses on the consequences for the population of severe weather events and climatic anomalies (Gil-Guirado, 2017).

The second historical source are newspaper. Newspaper sources have been widely used for the reconstruction of historical floods (Rashid, 2011; Gil-Guirado et al., 2016; Barriendos et al., 2019). In this paper, newspaper sources are only available for the 1879 floods and the local newspapers of the time were consulted. In addition, various files, books, expert reports, and chronicles have been consulted - and these constitute the third source of historical documentation used. All the above documentation is available at the Murcia Municipal Archive (MMA) and the Murcia Provincial Historical Archive (MPHA). The analysis of historical maps has been mainly based on the maps made by the Spanish Army during the Spanish War of Independence (1808-1814). These maps offer a high level of detail for the period and are available on the online portal of the MCU (2020). In addition, historical maps were consulted in the Hispanic Digital Library online portal (Biblioteca Digital Hispánica) and other maps were found in files and reports available from the MMA.

Methodologically, the hermeneutic analysis is focused on a critical review of historical sources consulted. Following other works, a contextual analysis of the texts is the main analysis tool of this methodology (Pfister, 2011; Nash et al., 2019; Glaser and Kahle, 2020).

With regard to the quantitative methodology we use data sources of present time and historical cartography in a combination of the methodologies proposed by Pérez-Morales et al. (2018) and Prieto and Rojas (2012) has been followed for the map analysis. Two factors need to be considered spatially for the historical and current assessment of flood exposure: the physical component (natural hazard); and the human component (Cardona et al., 2012). Information on the former has been obtained from data contained in the National System of Flood Zone Mapping (SNCZI by its acronym in Spanish) of the Ministry of Ecological Transition and Demographic Challenge (MITECO, 2020). This has been developed by the ministry, following the principles in the European Directive 2007/60 on the assessment and management of flood risks for river space management, risk prevention, and territorial planning. This source provides the results of hydrological modelling in vector format for various return periods 
(10, 50, 100 and 500 years). Models have been used for 10 (RP10), 50 (RP50), 100 (RP100) and 500 years (RP500). The information for the return period (RP) reports the surface occupied by water in each return period, and the height of the water in centimetres.

For the analysis of the current human component, buildings were considered in the form of cadastral plots available at the electronic headquarters of the General Directorate of Cadastre - part of the Ministry of Treasure (MH by its acronym in Spanish) - with data updated in 2019 (MH, 2020). The cadastral sources consulted were urban plots for each municipality in the study area. In relation to land occupation in the nineteenth century, the map of 1809 entitled 'Plan showing the Huerta of Murcia prepared for flooding if it is threatened by invasion of the capital by enemies' by Pablo del Villar is (available in the MECU, 2020) has been georeferenced and digitised. This map has served to indicate the study area of the historical region of the 'Huerta of Murcia'. A 'huerta' is a Spanish word describing an irrigated area with small well-defined plots for growing a variety of vegetables and fruit trees. Huertas are a type of market garden and are often found beside waterways near towns and cities in Spain. This map shows the main urban areas of the time in the study area. Despite the great level of detail in this map, the reality of the period may not be fully shown.

The area occupied by the historical medieval wall of the city of Murcia has been georeferenced and digitised based on the 'Plan of the fortification of Murcia' by Manuel Rodríguez Hita (1812) and available in the MECU (2020). Once the old wall was mapped, the height of the wall above the current level of the city of Murcia was established on the basis of various archaeological works. The difficulty of establishing a set value has led us to model two height scenarios. Each of these scenarios has been intersected with the height of the water for various RPs (10 and 500 years) to ascertain the magnitude of the floods that the wall could have protected against. According to Montes Bernárdez (2002) the medieval wall that still stood in 1837 was between 3 and 5 metres above the current level of the city. Other archaeological works (Navarro Santa-Cruz and Robles Fernández, 2002) indicate that in some sections, the wall was 6.5 metres higher than the current height of the surrounding streets at the time of its construction. Similar figures are given by Aguilera and Megías (2014). These authors state that the height of the wall at present is 3.4 metres above the current height of the street and a primitive ground level of -3.7 metres would produce a total wall height of more than 7 metres. In this work we consider plausible a homogeneous wall height of 3.4 metres above the current height of the city (Scenario A). However, Frey Sánchez (2000) indicates that most of the walls were 4.1 metres high when they were built. If we consider that, in a conservative scenario, the city has risen 2.5 metres above this original level, the wall would be 1.6 metres above the current city level (Scenario B).

In addition, the digitalisation of the map entitled 'Sketch of the Huerta of Murcia; sections into which it is divided: surface occupied by the flood of 15 October 1879, height that the waters reached in the flood and approximate statistics of the losses suffered' by Juan Belando (available in the Hispanic Digital Library, 2020) gives us a more approximate idea of the spatial impact of this event.

Finally, and to complete the cartographic comparison, the digitisation of the previous maps together with the digitisation of a current satellite image, has allowed us to analyze the changes in the course of the River Segura in the vicinity of the city of Murcia between 1809 and the present.

The maps have been made using the free QGIS software (QGIS Development Team).

\section{Study area and historical background}

The city of Murcia was founded on the initiative of Abderramán II in 825 AD. It is located on the left bank of the Segura River, on a strangled meander. The city was founded to establish a habitable and stable point from which to control the area and exploit the fertile lands of the valley, while being sheltered from the greatest threat in the area, flooding. To do this, it was necessary to make a huge effort 
to control the irregularity of the flows of a river that often abandoned its course to create new meanders (Lillo Carpio, 2000).

The region is characterised by low rainfall (slightly less than $300 \mathrm{~mm}$ ) with eight dry months, a summer drought, and marked inter- and intra-annual irregularity. In addition, average annual temperatures are high (over $18^{\circ} \mathrm{C}$ ) with hot summers and mild winters. These conditions increase water stress for human populations and biotic communities, as the months with the greatest water demand correspond to those with the lowest river flows and the lowest rainfall. The months of June, July, and August (Gil-Guirado and Pérez-Morales, 2019) are especially critical in this regard. Until a few decades ago, the predominantly agricultural economy and the calendar of local crops revolved around this natural system and the variability it produced.

The current municipal district of Murcia occupies 885.5 square kilometres, and historically two distinct areas have coexisted within this large territory. Firstly, the city itself, as well as its huertas and surrounding villages; and secondly, the 'county of Murcia' with population centres far from the city and a generally distinct economic behaviour that is subject to rural traditions, and where dry farming has always surpassed irrigation.

The agricultural nature of the city and its surroundings has been - as in all ancient settlements - the key factor in the location of activities, which in this case and given the climatic conditions, has resulted in 'water determinism' above all other needs. This situation had the effect that in the city of Murcia, the defensive needs of a territory that was on the border between the ancient Christian and Muslim kingdoms were secondary. The city walls were conceived as a defence against floods, rather than military attack (Fig. 1). Consequently, in the city of Murcia, control of the surrounding space from a high defensive position has not been a priority.

The medieval wall of the city of Murcia has its origin in the period of Muslim rule and it was built between the eleventh and twelfth centuries. Although the main role of medieval walls is usually defence against enemy invasions, the case of the city of Murcia is an exception since the main role of the wall has always been as a defence against river flooding (Roselló Verger and Cano García, 1975). Already in the seventeenth century the Murcian humanist and scholar Francisco Cáscales pointed out that the wall of Murcia was built to defend against enemy attacks, and protect against floods and epidemics (Cascales, 1621). García Antón (1993) highlights the key role played by the wall in protecting the city from the flooding of the River Segura. However, it was Torres Fontes and Calvo García-Tornel (1975) who best described the defensive role of the city walls against flooding.

However, recent change in the size of the city has meant that the huerta has gone from being farmland for horticultural products consumed in the city, to an area of urban land reserve, and so changing the basic organisational scheme of the traditional huerta. This area was characterised by environmental factors that generated a historical region and a variegated landscape, homogeneous as a whole, and differentiated from surroundings by the use of irrigation. The territory presents a historical and spatial continuum that goes beyond political-administrative divisions, since, although most of the huerta is included within the municipality of Murcia, the historical territory of the 'Huerta of Murcia' stretches into parts of five other municipalities (Molina de Segura, Alcantarilla, Santomera and Beniel in the province of Murcia, and Orihuela in the neighbouring province of Alicante) (Fig. 2). 

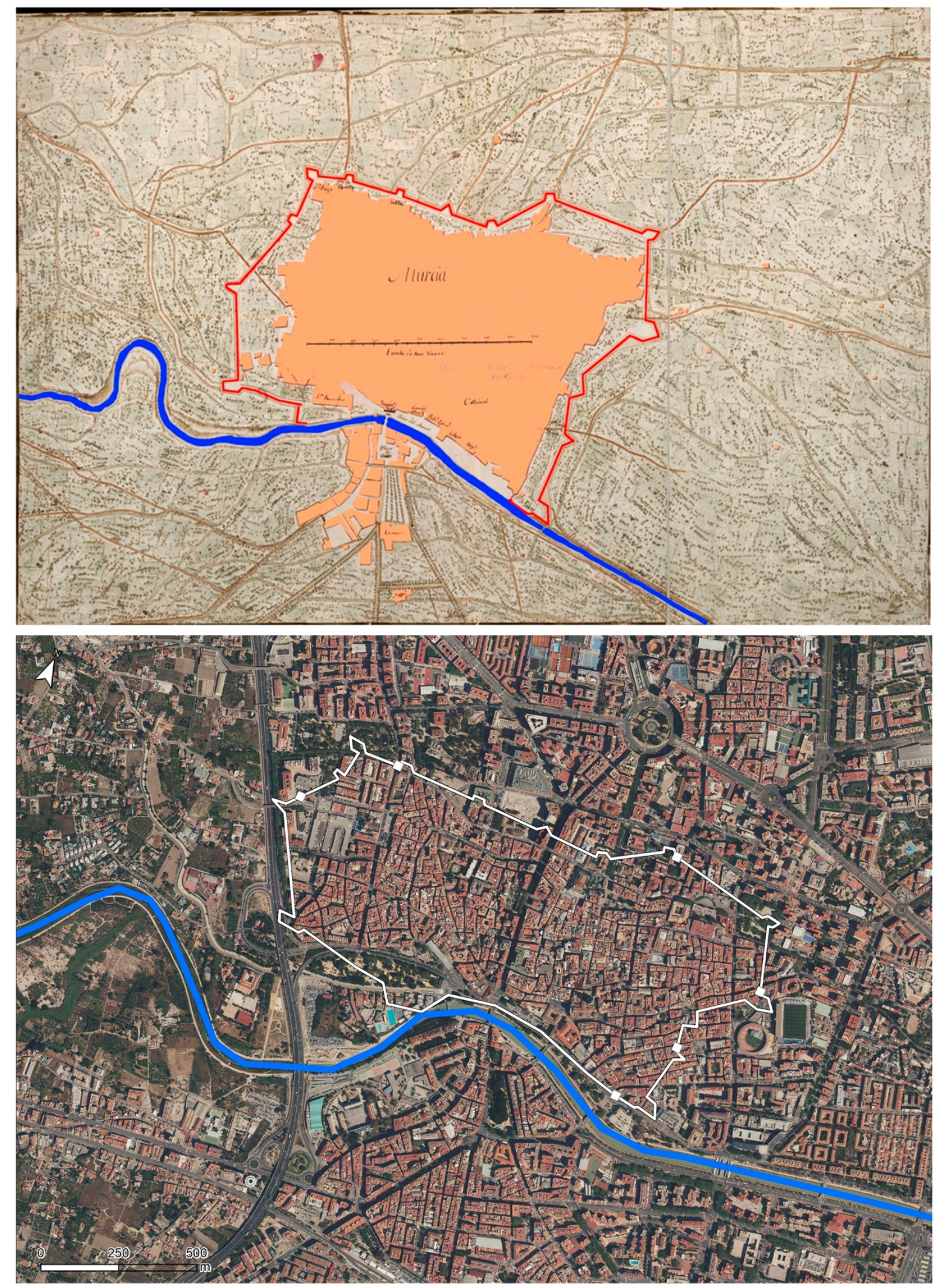

Figure 1. a) Plan of the fortification of Murcia (1812) by Manuel Rodríguez Hita; b) Current map of the city of Murcia, layout of the river and the Arab wall. Source: MCU, 2020. Note: the River Segura is coloured blue, the wall is red, and the urban area is highlighted in pink by the authors. 


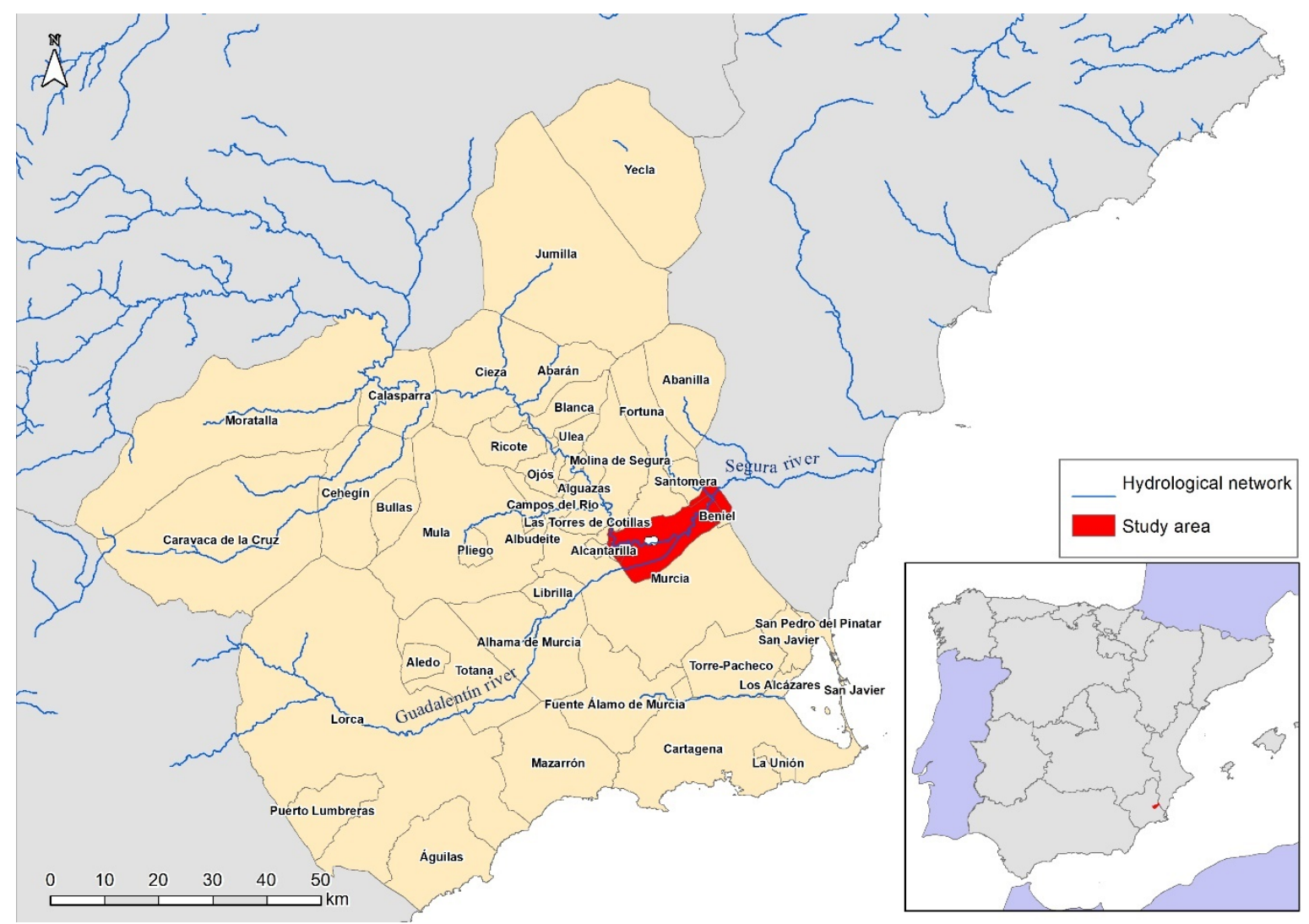

Figure 2. Study area. Notes: The perimeter of the study area corresponds to the historical region of the 'Huerta of Murcia'. The delimitation of this area has been made on the basis of an 1809 map entitled 'Plan that shows the Huerta of Murcia, prepared to be flooded if the capital is threatened with invasion by enemies' by Pablo del Villar available in the MCU (2020).

It can be seen how the River Segura, the huerta and the city of Murcia are intertwined in the functions of the metropolitan area, with a large part of the area being used for commercial purposes, except for some vestiges of irrigated crops (Fig. 2). This area corresponds to the Murcia Pre-coastal Depression, which is formed by of the River Segura and its confluence with the River Guadalentín. The alluvial plains - where farming is established - are made up of gentle slopes and fertile alluvial soils. The River Segura flows into the area in a NW-SE direction, with the width of its valley increasing as it approaches the city of Murcia. The Guadalentín flows naturally into the Segura, forming a large alluvial fan, a continuation of the valley floor, which runs along the Alhama fault in a SW-NE direction. However, in 1747 the Canal del Reguerón was opened to divert the River Guadalentín so that it did not join the River Segura upstream of the city. The edge of these valleys is marked by low hills.

The Huerta and the city of Murcia form the study area in this work and represent a part of the natural region identified with the valley of the River Segura after gaining width downstream from Archena and running between hills until reaching the neighbouring province of Alicante.

The natural confluence of the Guadalentín and Segura should be highlighted since the risk of flooding has determined the management guidelines of this area for centuries. This junction occurs upstream of the city in the place called 'Paso de los Carros' a few kilometres from the small town of Sangonera. The area forms a large alluvial fan (about $30 \mathrm{~km}^{2}$ ) in which the topography and regime of the river increase the risk of the river leaving the riverbed (Fig. 3). This is a determining factor in the exposure and danger of this territory to flooding. Throughout the history of the city, strategies have been in place to mitigate the risk that the torrential flow of the Guadalentín imposes on these lands (Calvo García-Tornel, 1969). 

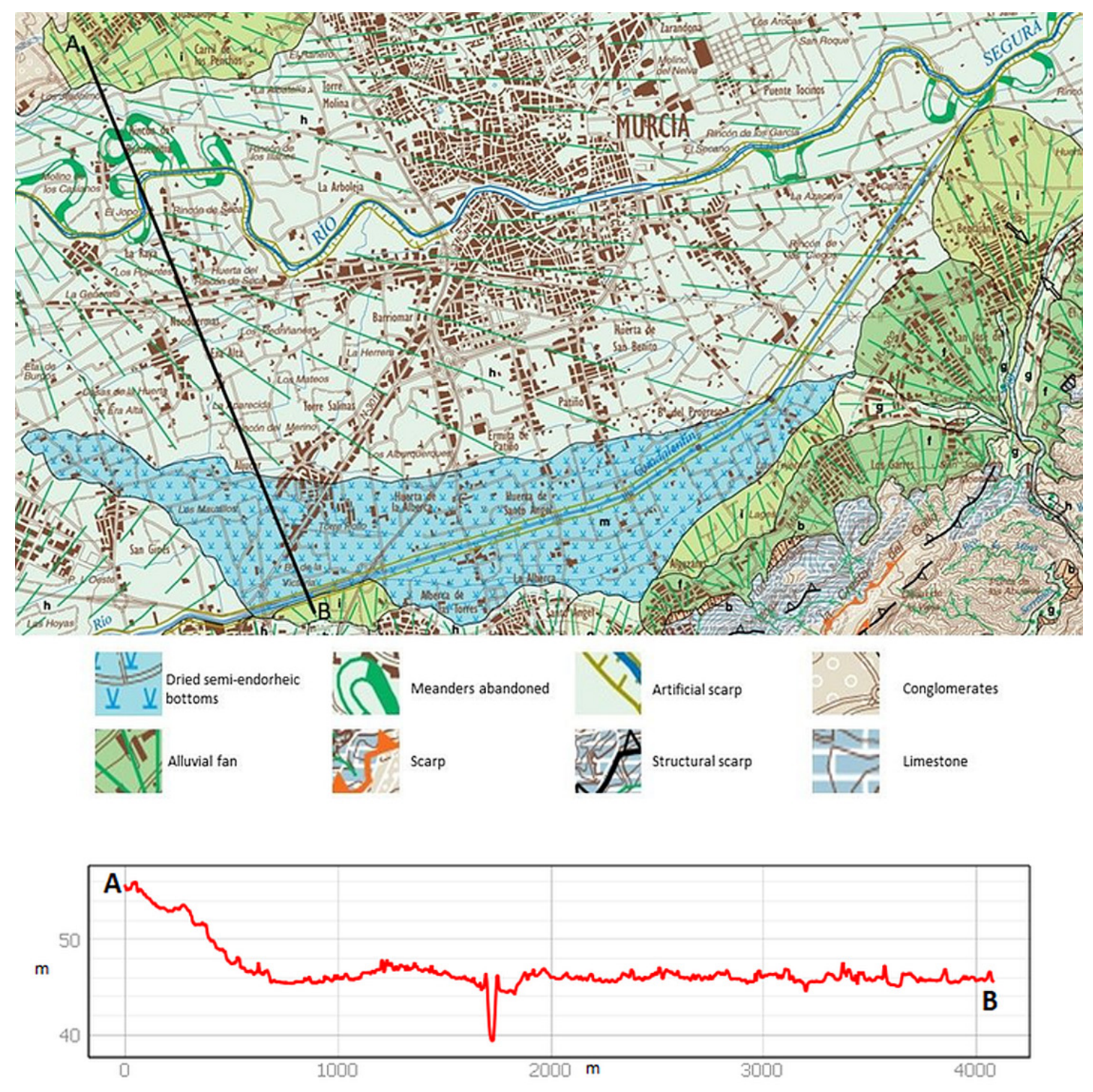

Figure 3. a) Geomorphological map of the confluence of the Segura river and the Guadalentín river in the city of Murcia and b) topographic profile. Source: Mapa Geomorfológico de España 1:50.000, IGME (2020)

This is the dual relationship that gives continuity and differentiation to the study area, given that it is characterised by the dominance and structural control of water, in order to escape from droughts and mitigate the natural lack of rainfall, while at the same time, controls are necessary to avoid sudden floods. Apart from the national and international economic and political context, these factors have determined the possibilities for regional growth, given that disasters are a burden, but the need to mitigate them is an incentive. Historical periods of development in the area, followed by population increases, were followed by periods of depression and stagnation as it was impossible to satisfy these new demands with the existing technology for farming and building structures to control water (Pérez Picazo et al., 1980). The origins of this process go back to the introduction of the irrigation system in the eleventh century - which has survived, practically intact, until the end of the twentieth century (Ros Sempere and García Martín, 2012). 


\section{Results}

\subsection{The Flood of San Calixto in Murcia (14 October 1651)}

The San Calixto flood of 14 October 1651 in Murcia was the most disastrous of the seventeenth century and, together with that of Santa Teresa in 1879, is one of the two floods that caused the most damage to the city.

Caused by intense autumnal rains, the sudden overflow of the River Segura caught the population unprepared (it occurred during the early hours of the morning - which was a repeated feature among catastrophic floods of the time). The damage reports tell us that the flood came from both the River Segura and the River Guadalentín, so the episode of rainfall was widespread throughout the River Segura basin (or at least in the W and NW areas). During the early hours, the city's population focused on reinforcing, with the means available, the city's defences to prevent an overflow, but a lack of resources compromised the effort.

Floodwaters ran through the city streets for three days. It was not until the fourth day that the city council was able to meet to assess the situation, which gives an idea of the size of the disaster. At an extraordinary meeting of the municipal council on 18 October, the members made a preliminary and desolate assessment of the damage. On the 19th (a Thursday), after a more thorough survey, the magnitude of the disaster was understood: buildings collapsed; livestock dead; defences swept away; a network of ditches destroyed; roads cut off; and worst of all, there were hundreds of fatalities. Such was the state of ruin that there was an exodus of survivors to higher parts of the Segura valley. The dire financial situation of the city increased vulnerability due to a lack of funds for repairs. Finally, it was agreed to accept the aid of the Crown with the subsequent exemption from taxes, the arrival of experts to assess damages, and funds allocated to help victims (Annex A. Doc. 1).

Damage to infrastructure was immediately followed by supply problems and a rise in food prices. As was normal in a disaster, neighbouring cities offered help. The first to offer was nearby Mula, despite the fact that it also suffered significant damage. One of the Crown's measures was to create a tax for all the towns of the old "Kingdom of Murcia" -territorial jurisdiction belonging to the Crown of Castilla- according to their population size to fund the reconstruction of Murcia city. The city council also required all the residents, without apparent distinction of social class, to collaborate in the repair of roads and flood defence infrastructures.

One month after the flood, the streets were remained under water and full of mud. This seriously affected commerce. In addition, buildings were continuing to collapse due to the accumulation of humidity. More than two months later the situation seemed even worse: the irrigation system continued to further deteriorate, food was scarce and expensive, the river began to occupy new spaces in the flood plain (and so mills could not grind grain), and the population continued to abandon the city for other towns. In this context, the same manager actors indirectly pointed out that the state of vulnerability prior to the event was partly responsible for the hardship caused by the disaster (Annex A. Doc. 2).

The city seems to have overcome the worst some four months after the disaster. A thanksgiving ceremony was held (Annex A. Doc. 3). However, the infrastructure remained damaged for many more months. It seemed that during this period one flood was never completely overcome, when another occurred. Thus, when another severe flood arrived in 1653, the flood damage from 1651 had not yet been repaired. This flood of 1653 was preceded by another flood of lesser size that damaged the defence systems (Annex A. Doc. 4).

Considering the means available, the systems of prevention, control, and assessment of the threat were fairly well developed in Murcia. The problem was the socio-political and economic context. It is worth noting that even four centuries ago, floods were considered a risk that required specific prevention measures. Thus, at the end of the summer, city officials began to revise the irrigation and defence system in anticipation of the autumn rainy season (Annex A. Doc. 5 and Doc. 6). 
The first month after a disaster is the period when emergency work peaks, although repair work continues more than a year later. However, the first six months are when the greatest social impact is felt. Given the lack of resources, territorial problems remained considerable throughout the period and were difficult to resolve (especially the repair of the irrigation network and defence systems). From one year after the flood, adaptation measures in anticipation of future floods gain priority.

With regard to the danger, there is little information on the environmental cause of the flooding. Most of the relevant information refers to the high level of the river, and to a lesser extent, to the torrential rains and the large amount of material washed away. The seriousness of the situation forced a major effort to manage the catastrophe, help the victims, and regain stability. Most of the information refers to measures of this type. In terms of infrastructure, it was the irrigation system and, above all, the flood protection infrastructure that was most affected. Consequently, the economic disruption to farming and the problems of irrigation water supply were significant. Deaths and injuries deserve a special mention. Given the magnitude of the disaster, little importance was given to these issues in comparison with today. This was perhaps because the high mortality rates of the time, and low life expectancy, meant life was not considered as important as it is today. It is necessary to note that past perspectives and perceptions are being assessed under a current prism. At a socio-political level, it can be said that the entire social structure was affected (including urban and rural inhabitants, nobles, religious orders, merchants, and the rich and poor).

The lethal flood of San Calixto in 1651 was an important precedent for risk management in general. Constant municipal requests were made to the Crown for aid and tax exemptions (a type of declaration of disaster) and all the social agents affected were actively involved (Annex A. Doc. 7 and Doc. 8). Both high-ranking nobles and knights sent someone to work on their behalf in the recovery from the disaster. This possibility was open to all nobles, but if they did not have the money to pay somebody, then they had to work themselves. The repercussions among the ruling classes transcended the real needs of overcoming the disaster. Churchmen began an open battle against the knights and the city council. During the ceremony of thanksgiving for having overcome the flood, the priest complained that church officials did not have anybody they could send to work on their behalf - unlike nobles. In this way, the priest claimed in a populist manner that he shared the suffering of the common people (Annex A. Doc. 9). In this way, the reality that elites have appropriated legitimate popular responses to injustices, al every historical moment, and deflect the initial intention by introducing new actors according to their private interests. It is also evident that the generalisation of risk processes is not a specific consequence of modernity, as suggested by Beck (2002).

Historical documentation shows how the authorities sometimes blamed the rural population, mill owners, animal breeders, and even some town councillors, for faulty maintenance of the irrigation network and flood defence systems. Speculators were also blamed for food shortages. However, the frequent occurrence of floods in Murcia, together with the scarcity of available means, meant that people blamed nature for traditional problems that could not be avoided or prevented. Proposals made to overcome the disaster included important improvements to the destroyed irrigation and defence network as well as financial aid.

\subsection{The Flood of Nuestra Señora de los Reyes (6 September 1733)}

The flood of Nuestra Señora de los Reyes occurred on 6 September 1733 and was probably the most catastrophic of the eighteenth century. As in the previous century, flood defences were in a deplorable state. The inability to maintain the defences in an efficient and diligent manner, heightened the vulnerability and explained the major impact of the flood. Although the flood was much less damaging than the San Calixto Flood, it caused considerable stress for Murcia city and the huerta. Suffice to say that less than one month before the flood and despite the fact that the autumn rainy season was approaching, the irrigation system had been damaged, but excessive bureaucracy and a lack of funds 
prevented an immediate repair (Annex B. Doc. 1). Nevertheless, between 1651 and 1733 some improvements had been made to the protection systems, such as a straightening of meanders to give greater linearity to the river as it passed through the city. However, limited technical and financial resources compromised the effective application of these improvements, and above all, their conservation. The imposition of the wishes of local landowners over the public interest also played an important role in the situation prior to the flood (Annex B. Doc. 2).

On 6 September, an intense, continuous, and widespread rainfall led to a rise in the waters of the River Segura. Despite attempts to hold the banks, an overflow could not be avoided. Unlike in the case of the San Calixto flood, where the flood peaks came from both the River Segura and the River Guadalentín, the main part of this flood came mainly from the Guadalentín, and so it was less dangerous and the flows were less extreme. The immediateness of the response, the smaller scale of the flood, and because it occurred during the day, prevented a catastrophe with devastating consequences. Given the means available, the damage mitigation strategy was fairly successful in the beginning of the emergency, when rapid response groups were established to fix the damage to the defence systems and thus avoid further damage (Annex B. Doc. 3). Nevertheless, damage was considerable: mainly to crops; the irrigation and defence systems; and roads. Many homes and entire neighbourhoods were flooded. The poor quality of the buildings in the huerta led to many structures being washed away, and there were numerous deaths, although in much smaller numbers than a century before. Once again, the lack of a stable fund to provide for these frequent disasters made an immediate relief response difficult and left the local council without funds. There were immediate problems of food supply given the loss of crops, the destruction of crops, as well as the road closures and impossibility of milling. The result was shortages, hunger, and a major rise in the price of bread. In general, the urgent measures taken followed the same procedures as in the seventeenth century (Annex B. Doc. 4)

The notable difference between this event and that of 1651 is that while in the earlier episode it was necessary to wait four months to celebrate a church procession of thanksgiving for having saved the city from the flood, in this episode the ceremony was held just six days later. Reports said that the waters had mostly receded, and convents and some streets were already passable (Annex B. Doc. 5).

As in the seventeenth century, a damage report (which was perhaps exaggerated) was sent to the Crown. Two weeks after the flood, measures began to be taken to prevent further damage, and these focused on reducing meanders and rebuilding and improving the defence and irrigation systems. A lack of resources forced landowners to pay the costs of reconstruction. Landowners who refused or delayed were threatened with exclusion from these improvement works. Despite these efforts, 20 days later, the huerta and the city were still without water for irrigation and household use because of the breakdown in the infrastructure and the accumulation of sediment in the pipes.

On 30 September of that same year, another small flood made recovery more difficult. The warning systems were activated, and effective measures were established. In this case, the flood came from the River Segura and occurred gradually, due to rainfall in the upper river basin, and so there was time for the municipalities upstream of the city of Murcia to report the threat. In the end, the flow was less than expected, and the measures prevented another overflow (Annex B. Doc. 6). From November onwards, reports about this event began to decrease in the municipal records. During the following months, work continued on flood defence, irrigation, and road repairs. In March 1734, a relative recovery from the catastrophe was formally announced.

Awareness of the danger of flooding had increased in comparison to the seventeenth century, and more thought was given to preventing disasters and establishing adaptation strategies. High water levels were considered responsible for the flooding by many observers, but there was an increasing focus on the torrential rains, and above all, the materials washed away by the river, as the cause of the damage. At the same time, some observers remarked that the real problem lay in the high level of erosion of the local materials. The most significant damage was to the irrigation infrastructure. However, there was also significant damage to roads. After these damages, the effects on farming, the occasional flooding 
of land, and the difficulties in evacuating water were significant problems noted in the municipal records.

Murcia's dependence on official assistance and financial credit, and the lack of foresight, led to serious economic problems. The lesser intensity of the flooding led to a reduction information in relation on fatalities and injuries compared to a century earlier. The inability of local government to critically assess risks and the greater level of intervention in the territory with the better level of understanding of environmental mechanisms than a century before, led to the blame being generally placed on nature. However, there was increasing awareness of human action as being responsible for the impact of flooding. In this respect, the technicians responsible for reviewing the infrastructure were blamed for the deficiencies in the defences.

Among the measures proposed to overcome the disaster, technological improvements with respect to the seventeenth century enabled the use of new construction techniques to reduce vulnerability. However, the key measure against floods continued to be the improvement of irrigation and flood defence infrastructures.

\subsection{The Flood of Santa Teresa (14 October 1879)}

The Santa Teresa flood was the most catastrophic flood ever recorded in Murcia. The material damage was incalculable, and the victims were counted in hundreds. The worldwide response to the distress of the Murcian people was unprecedented (Botrel, 2019).

The flood was caused by an intense rainfall that lasted more than two days and was widespread throughout the river basin. The flood peaks that reached the city came from the River Guadalentín, as well as from the rivers flowing towards the right bank (Rivers Mula, Quipar, Argos, and Moratalla) and also from the left bank of the River Segura.

The severity of the Santa Teresa flood made it necessary to manage quickly the catastrophe. The Murcia City Council held five consecutive days of extraordinary sessions (October 15, 16, 17, 18 and 19) to deal exclusively with the management of this flooding.

On 15 October the city was completely flooded, the newspapers echoed the disaster and given the impossibility of beginning the relief efforts, they reported on the first bureaucratic responses, such as the creation of a Relief Board (a similar in effect to declaring a catastrophe). From the very beginning, it was feared that the damage to the huerta could be much more serious than in the city (Annex C. Doc. 1).

A news story in El Diario Información on 16 October reported: "10,000 farmers have undoubtedly lost everything they had on this sad night; and soon they will come to our streets to tearfully ask us for charity, and the authorities must help them and give bread to those who are hungry. Today the King, the Government, the whole Nation, must know that this unfortunate city has been left poor and miserable; today the voice of Murcia will be heard throughout Spain asking for help for an immense number of its children who have lost everything."

Within the city of Murcia, the areas near the left bank of the river were the most affected. The San Benito neighbourhood (in the southern part of the city) was the first to be flooded, and as the epicentre of the catastrophe, the destruction was total. The water reached the city centre, flooding the entire San Pedro neighbourhood. The prison, the cathedral, and the neighbourhoods of San Juan and San Andrés were also flooded. The situation was worse in the huerta, with bodies scattered in the fields near to the city. The district of Nonduermas was completely inundated, as were the districts of Era Alta, Beniaján, Alquerías, Aljucer, Rincón de Seca, La Alboreja, San Benito, El Raal, Urdienza, and Puente Tocinos. By the 16 October, some 113 deaths were already reported despite the fact that the most affected areas were yet to be reached. In January of the following year, the official figure for victims was given as 148 , although with the many missing people, the number was probably some 300 for the 
capital and huerta. In Orihuela, in the neighbouring province of Alicante, bodies from Murcia were found in the river.

The disaster attracted widespread attention in Spain and abroad, and King Alfonso XII visited the affected area on 20 October. The mobilisation of international charity was unprecedented, especially from former Spanish colonies and those that still remained (Cuba, the Philippines, and Puerto Rico). France also sent considerable aid, where the Parisian press gave considerable coverage to the event, creating a fund to help those affected and a lottery to raise funds. Help was most immediate from the other towns in the River Segura basin and the rest of Spain - and began arriving just two days after the flood.

Press sensationalism exaggerated the effects and made it difficult to obtain a clear idea of the magnitude of the damage (Annex C. Doc. 2 and Doc. 3). More than 20,000 hectares of the Huerta of Murcia were submerged, and much material was carried away by the water. In some places once the water was drained, the accumulated sediments reached almost two metres in height (Figure 4). The destruction was almost total and the damage incalculable.

Until October 22, the authorities only sought to provide relief, and from this moment onwards they began the work of rebuilding the flood defence and water distribution systems, while at the same time, they started to propose measures to avoid a repetition. These measures usually involved public works (Annex C. Doc. 4).

Newspaper reports noted a new class consciousness in the nineteenth century, differentiating between poor day labourers, landowners, and the rest. The improvement in individual and political freedoms, together with the relative freedom of the press during the reign of Alfonso XII, is evident in a greater critical capacity that pointed directly to several social practices as responsible for the destructions caused by the flood. However, following the flood, corporatism and political control of the media were also felt. On 16 October 1879 the 'Diario de Murcia' supported the ruling political powers and security forces with a front-page story that commentated: 'yesterday throughout the huerta we saw how all the councillors, the Civil Guard, firefighters, and security forces, as well as hundreds of members of the public, continued to provide relief to those in need'. The newspaper went on to suggest that the cause of the flood was divine: 'It seems that God is angry at the city of Murcia'. The political support was confirmed on the 19th: 'We repeat that in Murcia there has been no authority, nor individual with responsibilities, who has not done everything that could be done'. To this position was added an ultraconservative opinion that considered the poor - who were accused of numerous vices and bad habits - to be responsible for the social problems. A news story published on 25 October 1879 in El Diario de Murcia is the best example of this, and it also indirectly illustrates some of the secular problems of the population of the Segura Valley, such as a lack of a spirit of protest, conformism, and religious faith (Annex C. Doc. 5). This news story is almost an insult and serves as an example of how social tensions were increased by the flood. The same newspaper was also forced to respond to criticisms made by the more progressive and educated sections of Murcian society - who were too afraid to publicly make their observations (Annex C. Doc. 6).

From December 1879 onwards there were constant problems in the distribution of aid, and it was said all of the donated funds were being made available. Most of the funds were donations from individuals and were given to help the neediest, but it seems that a part of this aid was re-directed to help large landowners and the upper classes. Again, some sectors of the local press showed their support for local cronyism and so evidenced that social problems were an important factor of vulnerability. It also became clear that the most conservative sectors were the least inclined to spend funds on improving adaptation and resilience, and were opposed to reconstruction beyond the safest areas (Annex C. Doc. 7). Nearly three months after the flood, a realistic assessment of the number of people affected was made, and it highlighted that 9,332 people in the huerta had not yet been provided with clothing (while 20,000 had been given clothes). However, reports on the amount of damage were still contradictory (Annex C. Doc. 8). 

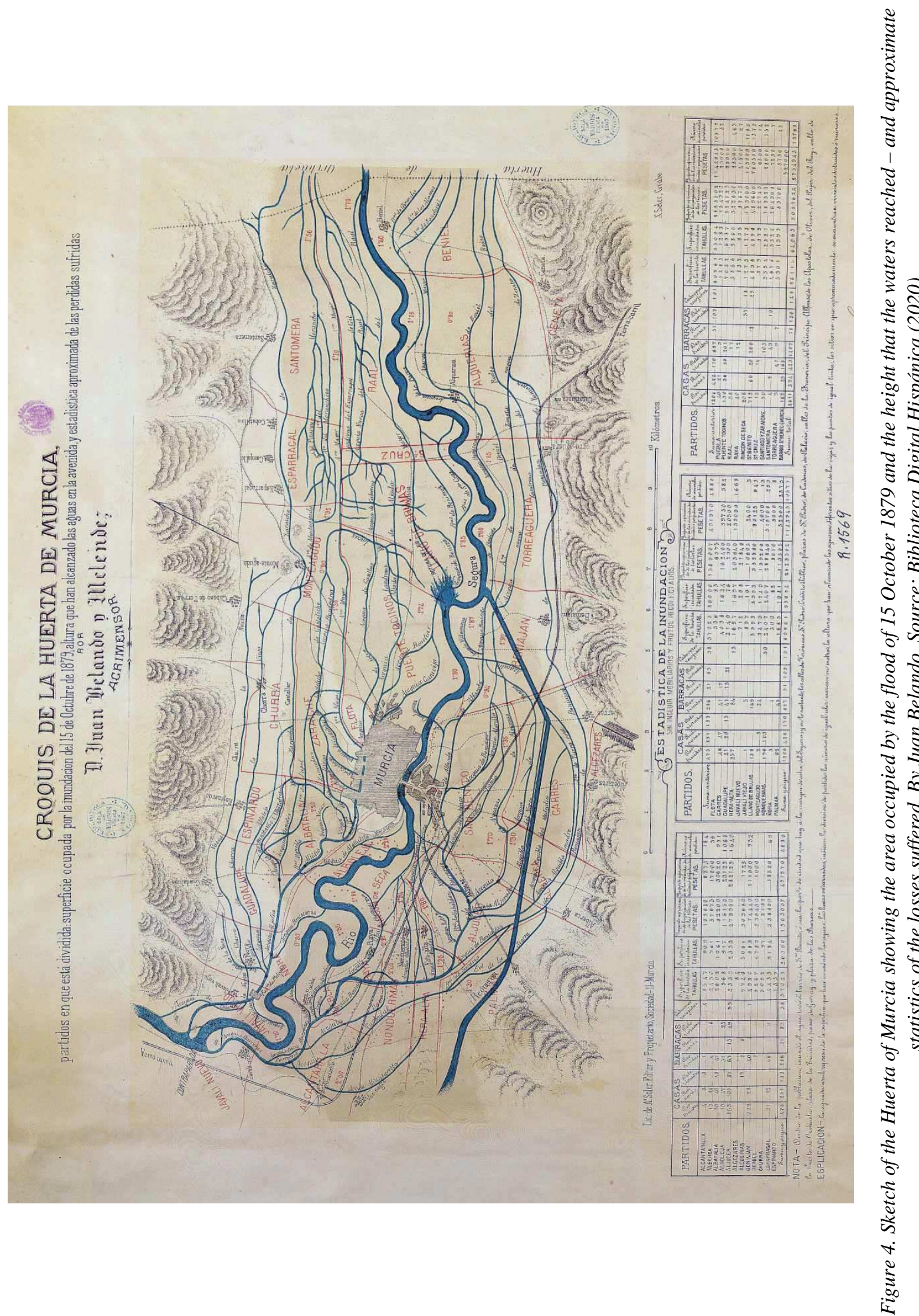
By March 1880, the flood was being overcome, or rather internalised, by the general public. Given the magnitude of the disaster, the effects continued for months and even years, while destroyed estates, houses, and roads were being rebuilt. However, by this time, normality began to return. Once again, the small farmers realised that their fate was to become poorer and more miserable than they had been just a few months before. An El Semanario editorial of 17 March 1880, addressed to two politicians (including General Manuel Cassola) explained this reality, as well as the continuing problems with the distribution of aid (Annex C. Doc. 9). The efforts to overcome the disaster continued at least until the end of September 1880 (almost a year later). Despite the magnitude of the disaster, less time was needed to solve the most obvious flooding problems when compared to events with comparable repercussions in previous centuries, such as the San Calixto flood.

The hermeneutic analysis shows that this flood reveals a large increase in exposure with an absence of improvements in the systems of defence, mitigation, or prevention. The population of the city had risen from 19,320 in 1755 to 29,949 in 1887. During this same period, the population of the Huerta of Murcia grew from 50,156 to 74,873 (Marset Campos et al., 1981). However, a more widespread and rational use of new technology had induced a greater awareness of the natural danger of flooding. For the first time, sloping land was considered as dangerous. It should be noted that academics also pointed to deforestation as responsible for the increased impact of floods (Echegaray, 1851; Rico Sinobas, 1851; Hernández, 1885; Diaz Cassou, 1887).

Despite the enormous damage, disaster management was better than in previous centuries, mainly due to the aforementioned technical improvement and investments policy in infrastructure. As far as adaptation measures are concerned, the comparatively better budgetary situation in Murcia meant an improvement when compared to previous floods. However, problems increased in farming and livestock, as well as the flooding of land, while the impact on infrastructure was reduced. In the other hand, the estimates of deaths and injuries increased notably compared to previous floods analysed, in relation with the magnitude of the disaster.

There was greater social diversity of victims than in previous floods. However, it is evident that the impact affected more severely the least advantaged sectors, and children, the elderly, women, day laborers, and the poor appear in much of the information on those affected. Perhaps this is because the greatest damage occurred in the huerta - where the resident population was poor and generally engaged in farming.

At the same time, social conflict increased, although it was limited as the size of the disaster produced a certain solidarity and mutual understanding among those affected, or simply because the population was so exhausted and affected that public calls for accountability were not made. We must also consider the effects of the political manipulation of the news.

As far as the general causes are concerned, the available factual evidence meant that less blame was placed on nature and more on human actions, although not as much as was justified given the technical advances and the new nineteenth-century scientific paradigm. Again, this is explained by the manipulation of information. This can be seen from the fact that newspapers in Murcia pointed to poor farmers, and to a lesser extent the defence system and politicians, as the main culprits.

Adaptation measures experienced a major qualitative leap in the wake of this disaster. Positivist currents of the time were influenced by the fact that a large number of congresses and technical meetings were studying the danger of flooding in Murcia. The state of destruction was such that this was seen as an opportunity to reconstruct and build a better adapted system. Various administrative reforms, an improvement of construction techniques, and the rebuilding of houses in less exposed areas, were some of the new solutions considered. However, many measures were not carried out in the appropriate manner due to the conservatism of the existing powers, which meant that the most important measures continued to revolve around improving the flood defence systems. 


\subsection{Historic maps and defensive infrastructures against flooding in the Huerta of Murcia}

The Huerta of Murcia and the city have grown in parallel with the solution to the problems caused by the River Segura. Depending on the technological possibilities, policies have developed over the centuries to rectify the course of the river. These policies were first developed between the fifteenth and nineteenth centuries (Roselló Verger and Cano García, 1975). In parallel with the expansion of the irrigation system, the growth in the settled population forced awareness of the greater risk of flooding due to increased exposure. Retaining walls were built, the most important being the Trenque del Chillerón, Trenque del Don Payo, and the most significant for the defence of the city of Murcia, the Muro del Malecón (first built in the fifteenth century and rebuilt in 1736). This latter infrastructure was three metres high, more than $1.5 \mathrm{kms}$ long, and surrounded the west side of the city. Much of this wall still contains the river water as it passes through the city centre. These works corrected seven large meanders of the river between 1593 and 1692, most of which were near the city of Murcia, and there is also ample documentation available from the sixteenth century (Calvo García-Tornel, 1972) (Fig. 5).

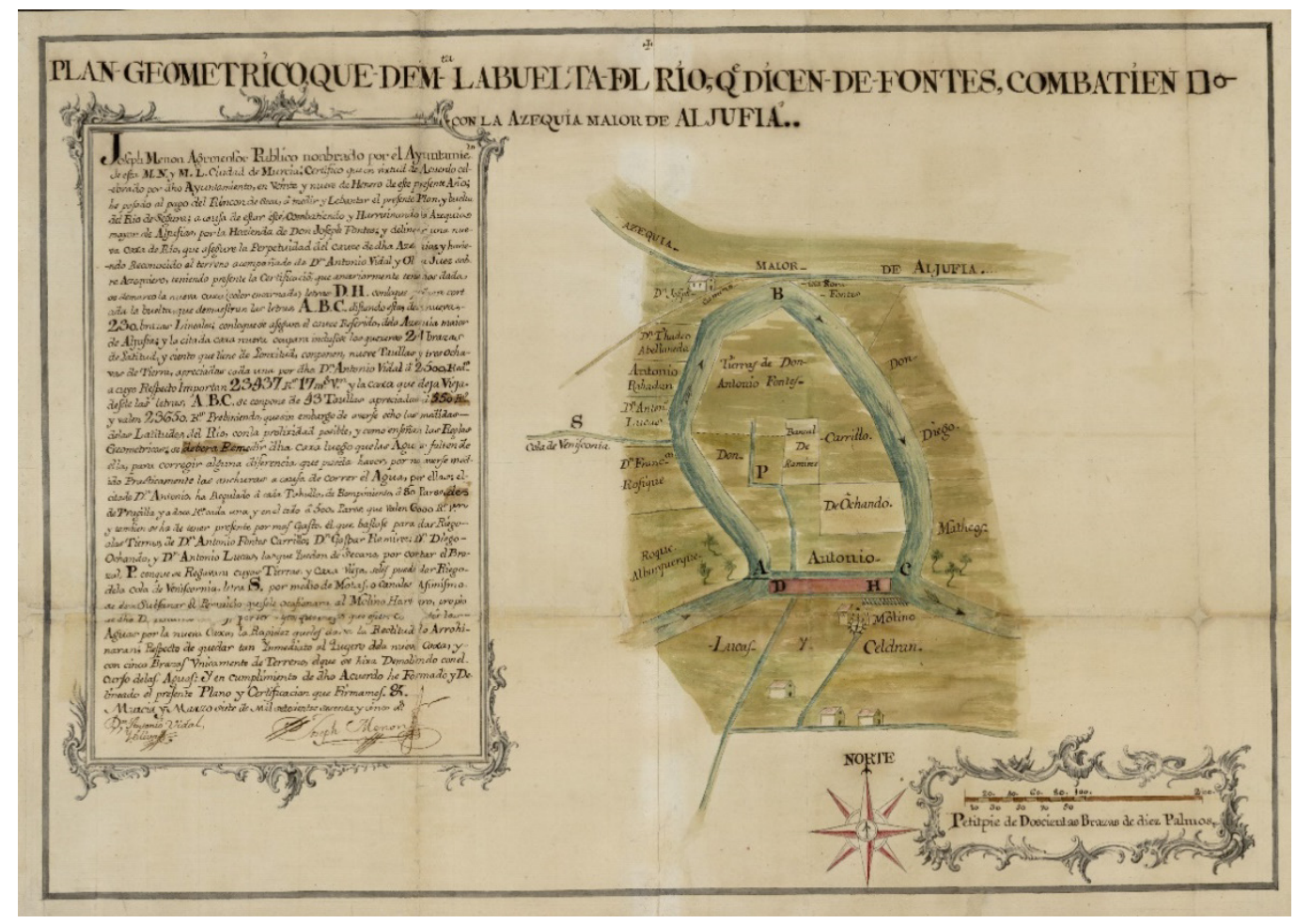

Figure 5. Map of 1765 showing the intended cutting of a meander in the River Segura due to its effects on the Aljufia irrigation channel. Source: Murcia Municipal Archive (MMA).

Changes in the length of the River Segura in the study area are evidence of this process of straightening of the riverbed over the last two centuries. These changes have been carried out mostly in the meanders upstream of the city of Murcia and also in the stretch between Murcia and the district of Alquerías (Fig. 6). Changes in the length of the river are indicative of the new trends in fluvial policy. In 1810, the length of the River Segura as it passes through the huerta area of Murcia was $40,088 \mathrm{~km}$, by 1879 this figure had dropped to 33,922 km, before falling to 32,704 km in 2019. A reduction of $14 \%$ and $18 \%$ respectively and in absolute terms, the River Segura has lost more than seven kilometres in length in the study area over the last two centuries. 


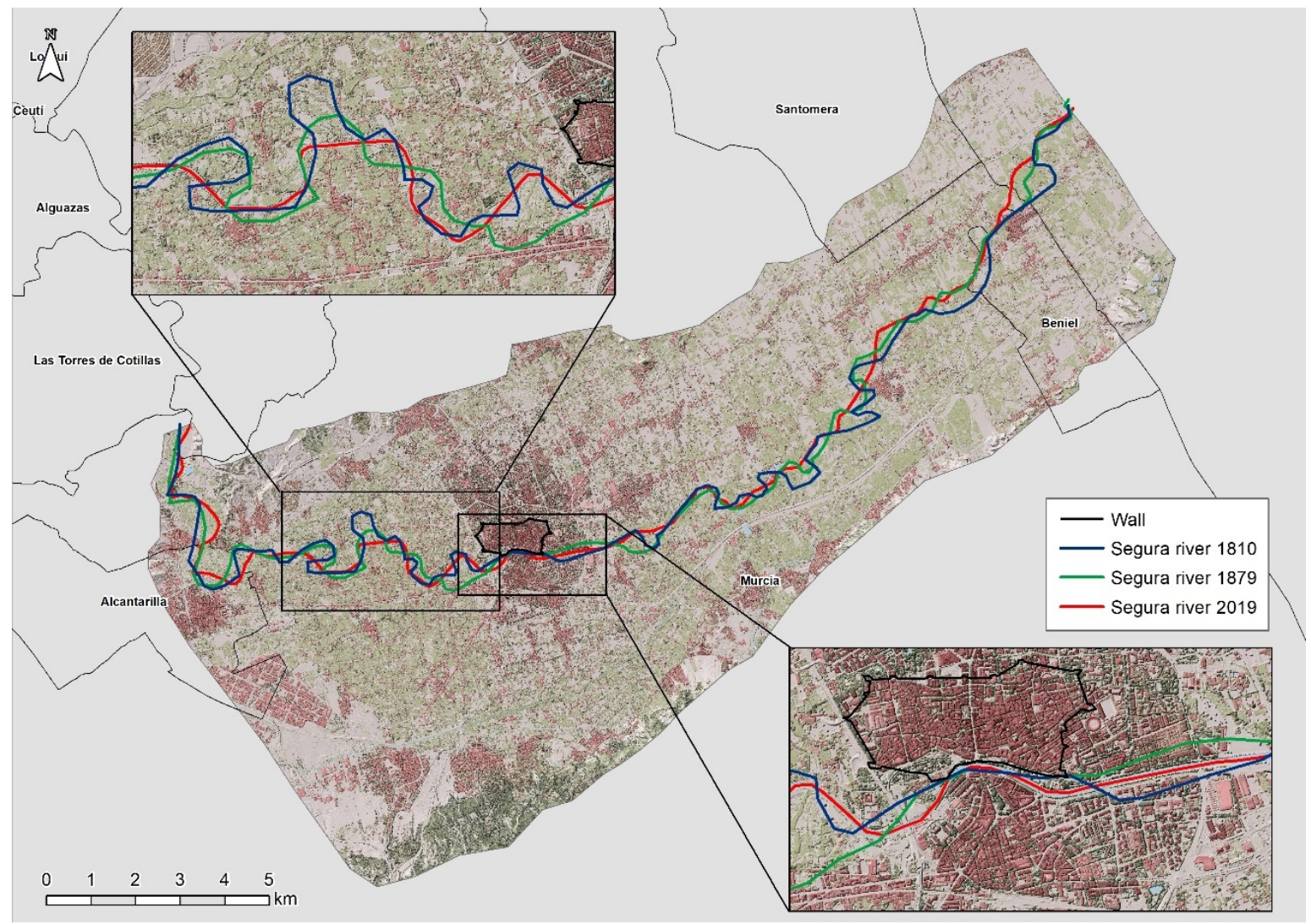

Figure 6. Changes in the River Segura as it passes through the city of Murcia over the last two centuries. Sources: the riverbed in 1810 is drawn from the map of Pablo del Villar of 1810 (MCU, 2020), the riverbed in 1879 is drawn from the map of Juan Belando 1879 (Biblioteca Digital Hispánica, 2020), the riverbed of 2019 is taken from a satellite image of the 2019 National Aerial Orthophotography Plan (PNOA) of the Ministry of

Development, through the General Direction of the National Geographic Institute (IGN) (2020).

The irrigation system is also a threat to the population, due to the risk of flooding and expansion of the floodable area, but it has been planned and strictly controlled in a manner similar to a military defence system. Thus, in 1706 during the War of the Spanish Succession, Cardinal Belluga ordered the breakage of the dikes to flood the Huerta of Murcia and so prevent the city from being taken by troops loyal to the Habsburgs. Similarly, during the Spanish War of Independence, military defence plans included the controlled flooding of the huerta, to prevent the entry of Napoleonic troops. Figure 7 shows how entire irrigation network of the Huerta of Murcia was conceived as an integral defence system against external enemies.

The eighteenth century saw a boost to the flood defence of the Huerta of Murcia. Calvo GarcíaTornel (1972) remarked that thanks to an expanding economy this was the first time that solving the problem of flooding was approached in a comprehensive manner. During this period, an artificial bypass channel was completed to divert the erratic and torrential floods caused by the River Guadalentín before passing through the city of Murcia. This work became known as the Reguerón Canal and is still in service today. At the same time, at the end of this century, construction began on the Puentes and Valdeinfierno reservoirs in the upper basin of the River Guadalentín, with the aim of increasing the irrigation water reserve for the Vega de Lorca and using the reservoir capacity to slow down the flooding of the River Guadalentín - the principal threat to the city of Murcia. 


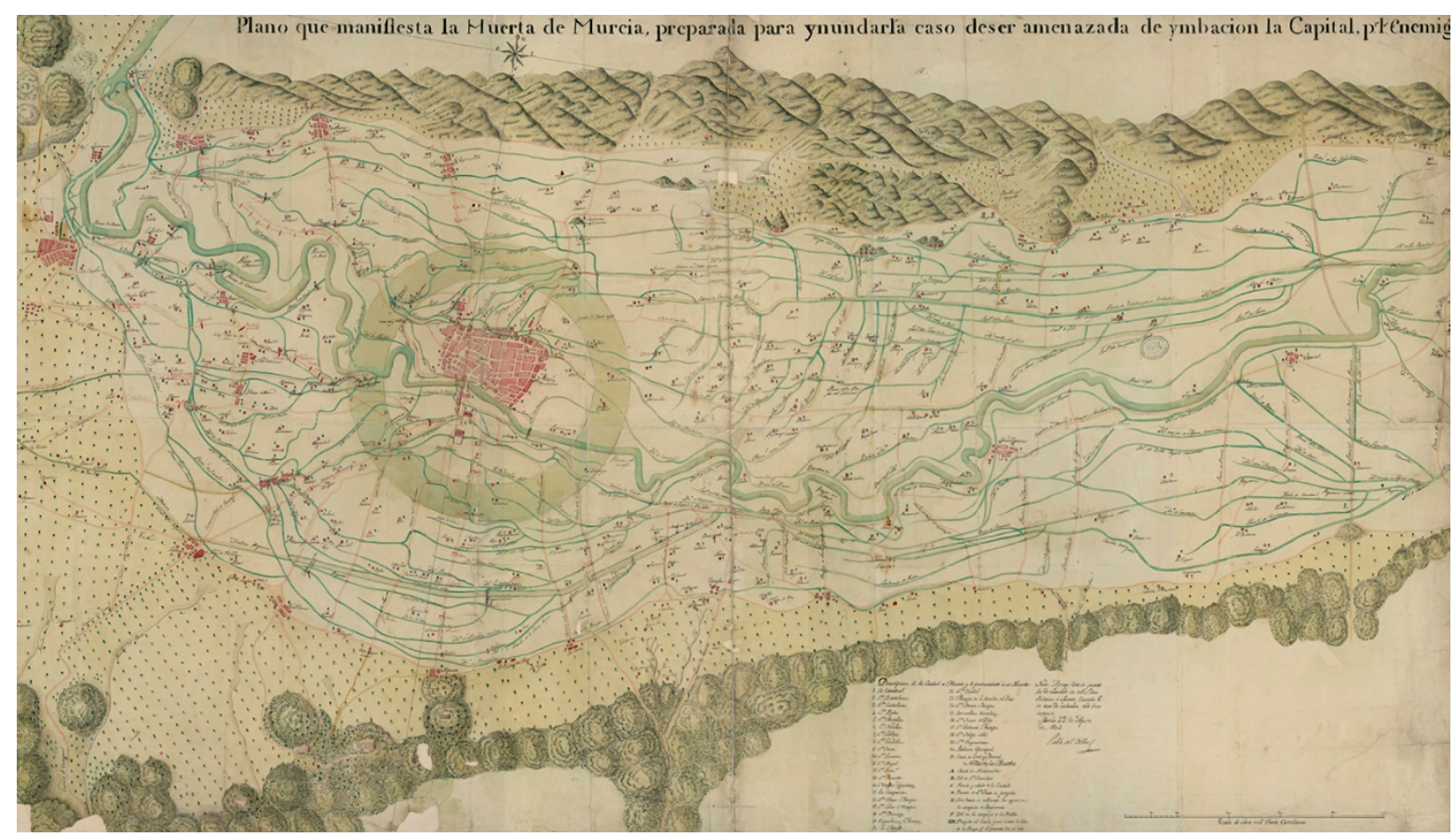

Figure 7. Irrigation system of the Huerta of Murcia, structure, and possible defensive roles: 'Plan showing the Huerta of Murcia prepared to be flooded in case it is threatened by invasion of enemies'/ Pablo del

Villar'. 1809. Source: MCU, 2020.

Once again, the lack of continuity in the technical, economic, scientific, and political initiatives, reduced the effectiveness of the strategy of adaptation to the risk of flooding. According to Pérez Picazo et al. (1980), the economic crisis that began in the second half of the eighteenth century produced a technological blockage that prevented an improved adaptation to the environment. Nevertheless, science and technology closely followed the climatic variations of the nineteenth century, which were characterised in the study area by severe droughts and raging floods (Gil-Guirado et al., 2019).

In this last aspect, the catastrophe caused by the Santa Teresa flood was highly relevant. The dimension of the tragedy, together with a new awareness of how to respond to the secular danger of the rivers Segura and Guadalentín, influenced a positive change in river management policy. The new policy focused on strengthening the banks of the river and regulating the tributaries of the Segura (especially the Guadalentín). At the same time, the Reguerón Canal was rebuilt, and a new diversion channel was built (the Paretón de Totana) with the aim of sending the waters from the Guadalentín directly to the sea (Calvo García-Tornel, 1972). The mapping of the Santa Teresa Flood (Fig. 8), showed that the area with the highest sediment and water level was in the old area of confluence of the Rivers Guadalentín and Segura (in the vicinity of the towns of Nonduermas and Era Alta). The role of the Reguerón Canal was decisive in limiting the impact of the flooding within the city of Murcia. However, the waters from the Canal del Reguerón caused great damage to the east of the city of Murcia, around the town of Beniaján. In other words, already by 1879, the flood defence system in the Huerta of Murcia was designed to lessen the risk in the city but to the detriment of the surrounding rural areas. This was corroborated in the previous section, by analysing how the damage caused by this flood was greater in the huerta than in city centre. 


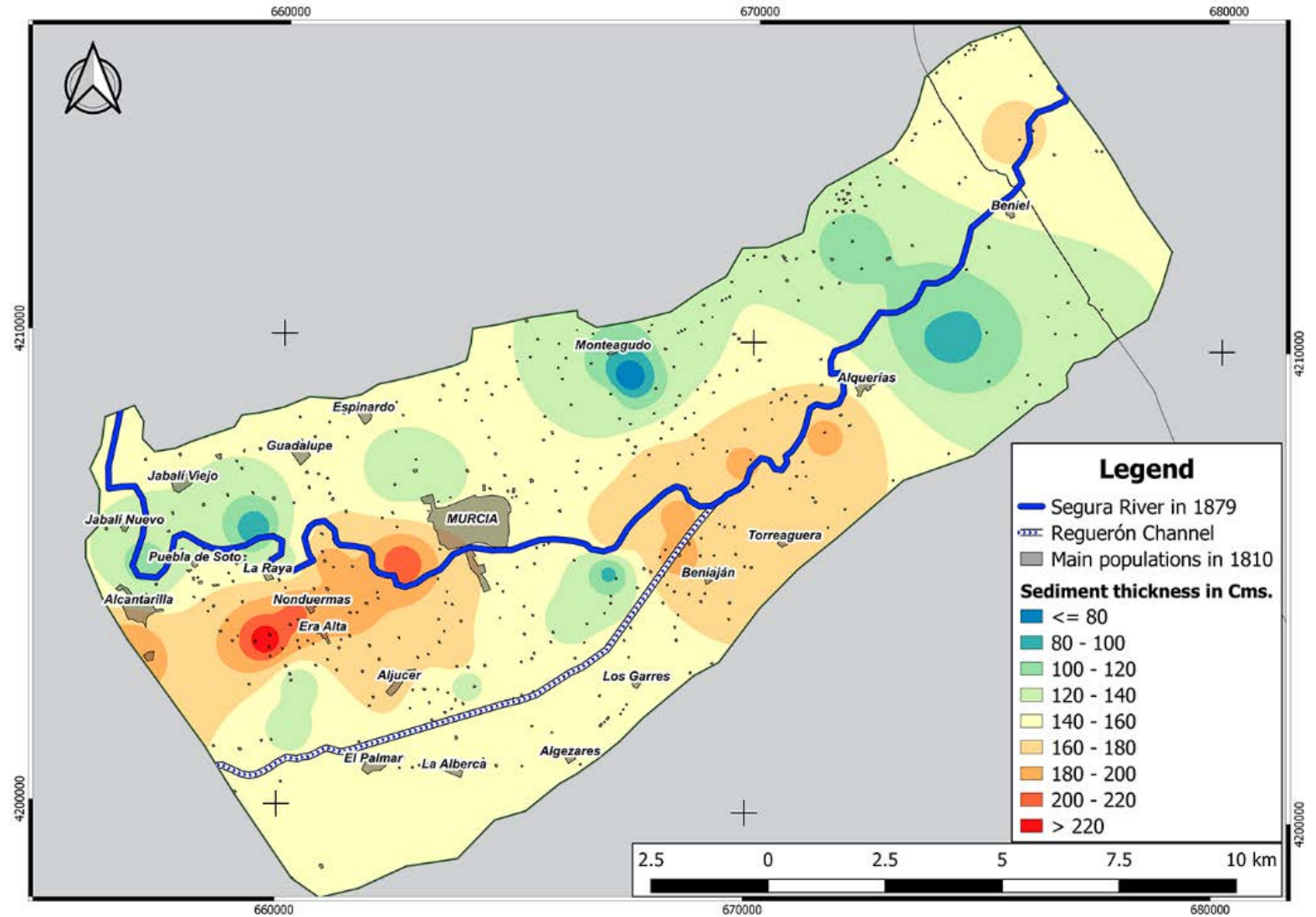

Figure 8. Sediment thickness (in centimetres) caused by the Santa Teresa Flood in the study area. Sources: the sediment heights are taken from a map of 1879 by Juan Belando (Biblioteca Digital Hispánica, 2020), while the populated areas are digitised from a map of 1810 by Pablo del Villar (MCU, 2020).

The suppression of meanders around the city of Murcia is also an example of how the flood defence system of the Huerta of Murcia was managed radially, in order to lessen the risk in the central city even at the cost of transferring the hazard to the immediate rural environment. However, perhaps the most paradigmatic example is the medieval city wall - which was conceived as a flood protection wall. In this respect, it is worth asking whether the conservation of this wall today would reduce the danger of flooding in the city centre. In the hypothetical scenario of the wall being preserved, being totally watertight, and having a minimum height of 3.4 metres above the current height of the city (Scenario A), it would represent a defence for the city centre against flooding with a return period of up to 500 years. However, if we consider these same assumptions but for a height of 1.6 metres of wall (Scenario B), then flood waters would penetrate the wall with a return period of 500 years. In both scenarios, the wall would protect against return periods of 10 years. An important point is that the most dangerous areas are located in the eastern half of the historic city (Fig. 9). If we consider Scenario A to be valid, the water would probably not have penetrated into the interior of the city, and it would have caused less damage during the Santa Teresa and San Calixto floods. 


\section{Scenario A $(340 \mathrm{~cm})$}
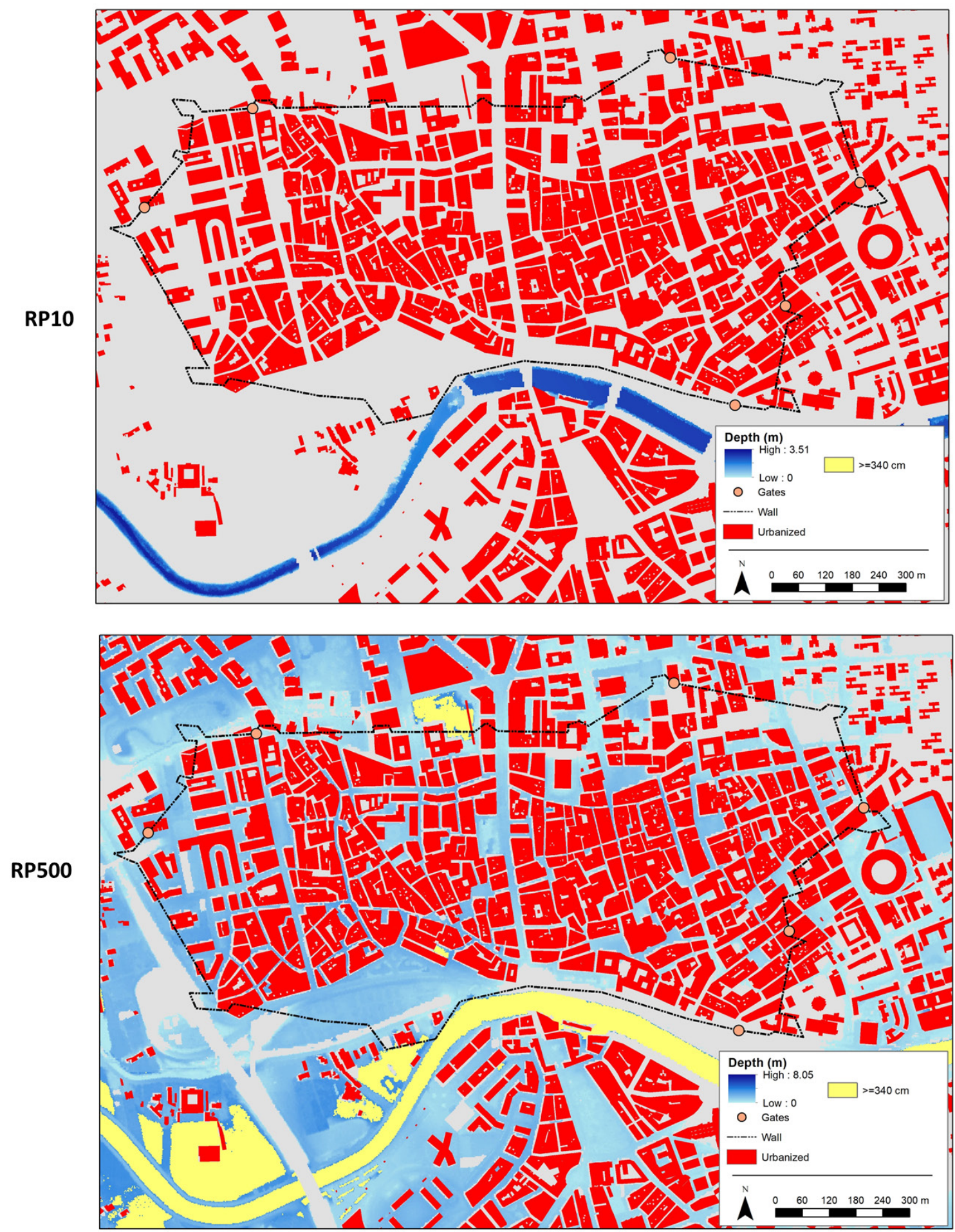

Figure 9. Modelling of the hypothetical role of the ancient medieval wall of Murcia in flood defence today.

Source: the perimeter of the wall has been digitised from the 'Fortification plan for Murcia' of 1812 by Manuel Rodríguez Hita (MCU, 2020). The height of the water level has been obtained from MITECO (2020) for the short RP10 (10-year return period) and more extreme RP500 (500-year return period). The polygons in red are urban plots and were obtained from MH (2020). 
Scenario B $(160 \mathrm{~cm})$
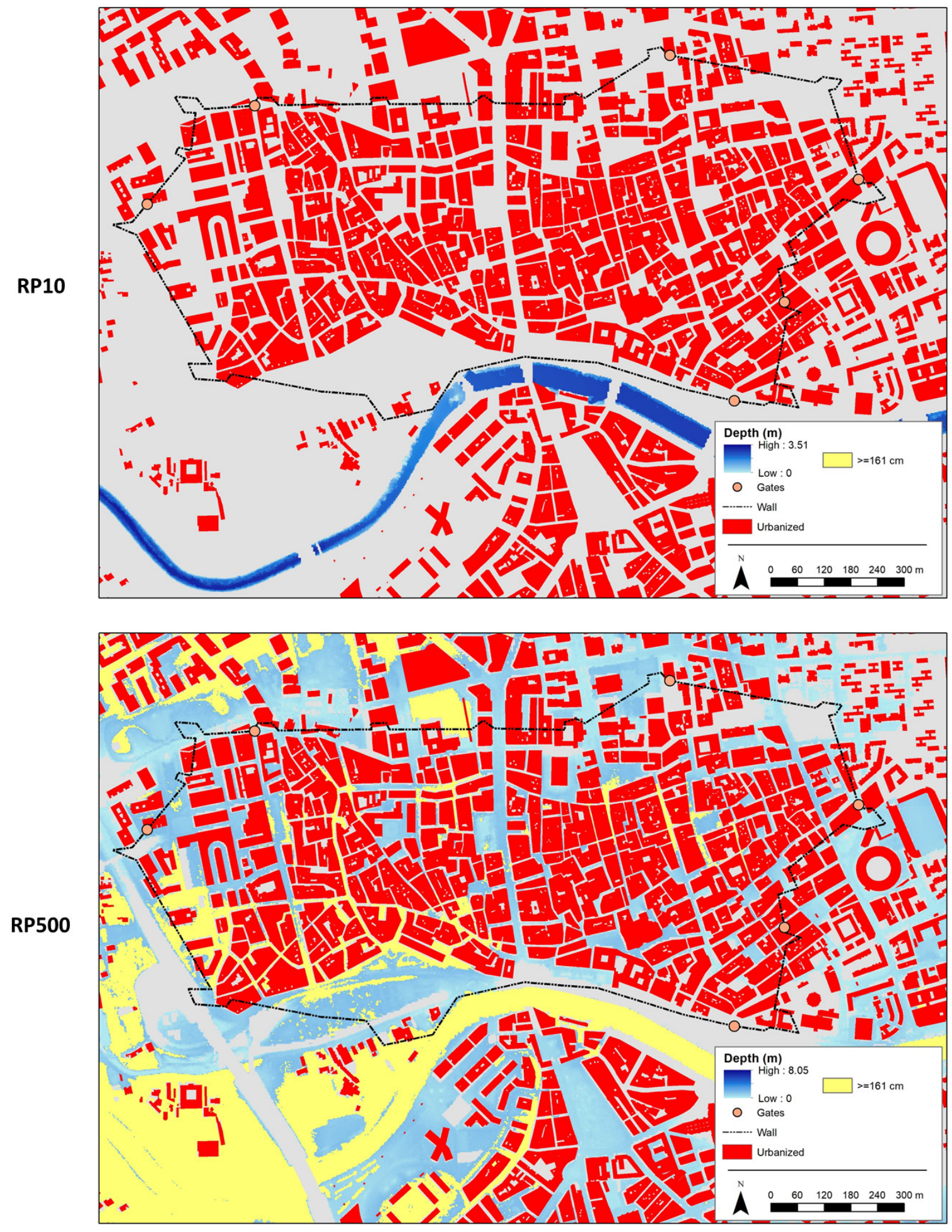

Figure 9 (cont.). Modelling of the hypothetical role of the ancient medieval wall of Murcia in flood defence today. Source: the perimeter of the wall has been digitised from the 'Fortification plan for Murcia' of 1812 by Manuel Rodríguez Hita (MCU, 2020). The height of the water level has been obtained from MITECO (2020) for the short RP10 (10-year return period) and more extreme RP500 (500-year return period). The polygons in red are urban plots and were obtained from $\mathrm{MH}$ (2020). 


\subsection{Past and present of the exposure to flooding in the Huerta of Murcia}

A key issue in the analysis of historical risks is based on the question of whether historical societies, considering their technical possibilities, were more vulnerable and averse to danger than current societies. Sometimes this research question is approached from an idealisation of the ancient as superior to the present, without considering the changes in cultural, economic, and political contexts. But above all, this question is sometimes addressed without a real assessment of how exposure and vulnerability have changed over time. In the case of the Huerta of Murcia, for the first time a comparison has been made of exposure to flooding in absolute and relative terms over a lengthy period of time. It is necessary to take into account that this analysis is carried out through historical maps, and that therefore, the values referring to 1810 are susceptible to biases, data gaps, or locational errors related to the adaptation of the georeferencing to the projection system. It is also necessary to remember that hydrological modelling is used for the current scenario, so there may be significant differences with the situation in 1810. There have also been changes to topographic and hydrological factors, as well as the flood defence infrastructure. However, this analysis is the best approximation yet made in the study area.

The first point is that the study area is largely within an area that is subject to flooding. More than two-thirds of the study area is susceptible to flooding in some return period. However, there are notable differences depending on the return period considered. While the return period with the highest recurrence (10 years) is present in marginal and little urbanised areas on the southern and northern edges of the western half, the other return periods affect the study area as a whole (especially the 100-year return period and, of course, the 500-year return period). These return periods overlap with intensely urban areas. A large part of the city of Murcia is constructed in areas prone to flooding by RP100 and RP500, while other urban centres in the suburbs are exempt from the danger of flooding. The great leap that takes place between the RP10 and the other RPs is odd. In this respect, a high exposure to flooding is observed for the return periods of low recurrence (RP100 and 500), but a low exposure is observed for more frequent return periods (RP10). This is seen both currently and in the past. In other words, both in the early nineteenth century and today, the population was exposed to less frequent floods in an uncontrolled manner, but they have also been more careful about occupying frequently flooded areas. This is logical and reflects a partial knowledge of the environmental reality of the territory, as well as a perception of danger among the population and managers of the territory. However, the large increase in exposure to the danger of flooding that occurred between 1810 and 2019 is also striking (Fig. 10). This is to be expected given the socio-economic and demographic changes that have occurred over the last two centuries, and so it is interesting to analyse this pattern of change in more detail.

In absolute figures the urban area has increased from $3.8 \mathrm{~km}^{2}$ in 1810 to $18.4 \mathrm{~km}^{2}$ in 2019 - an increase of almost $500 \%$. The growth in absolute values of the urban space in flood zones is worrying. Less than $1 \mathrm{~km}^{2}$ of developed area was occupied by RP10 in 1810, but by 2019 this value had risen to $1.3 \mathrm{~km}^{2}$ (an increase of 340\%). In the case of the most recurrent return periods, the increase in exposure has been even more dramatic, with an increase of 6 and $9.3 \mathrm{~km}^{2}$ of floodable area for RP100 and RP500, respectively. However, it is curious that there has been a decrease of $0.2 \mathrm{~km}^{2}$ of floodable space for RP50. In other words, there has been an absolute decrease in the occupation of this type of floodable area, which must be due to the implementation of adaptation measures to reduce exposure. These figures suggest that despite an absolute increase in exposure to flooding, there has been an improvement in the adaptation model, derived from a reduction in vulnerability, which has led to a relative decrease in floodable space (Fig. 11).

While in 1810, 10\% of the urban area was occupied by the RP10 floodplain, in 2019 this figure had dropped to 7\%. However, the most important differences are found in the other return periods. While in 1810 almost $60 \%$ of the developed area was flooded by RP50, in 2019 this figure was $11 \%$. Even for the less recurrent return periods, these differences remain, since in 1810 some $88 \%$ of the developed area was within the RP500 floodable area, while in 2019 this figure, although also high, had fallen to $66 \%$. Therefore, while the absolute values show a large increase in exposure, the relative values show 
an improvement in the pattern of land occupation. This change in land use can also be seen in that in 1810 there was only more safe urban area than floodable area when intersecting for RP10, but by 2019 this pattern was also produced for RP50 and RP100.

1810

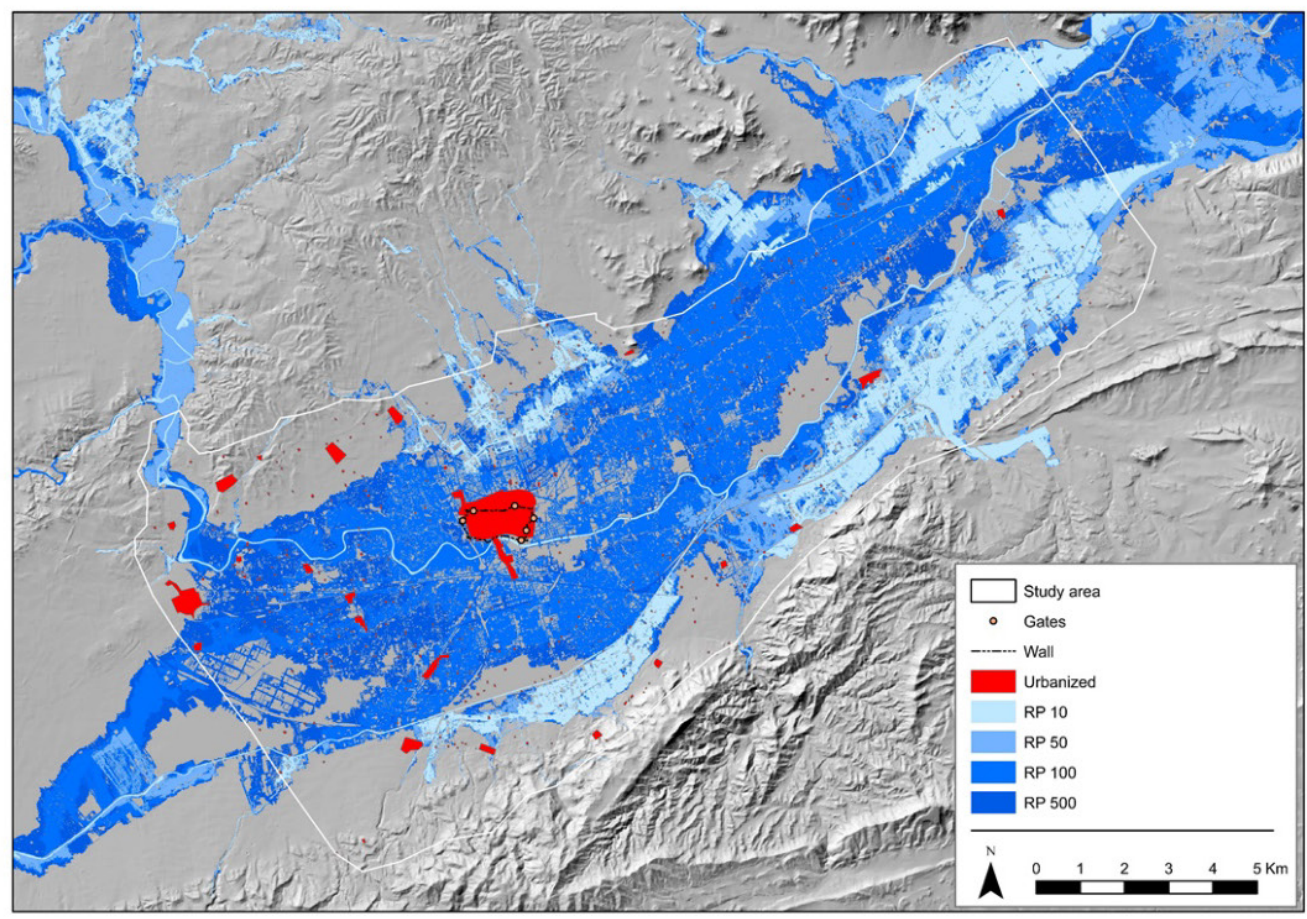

\section{9}

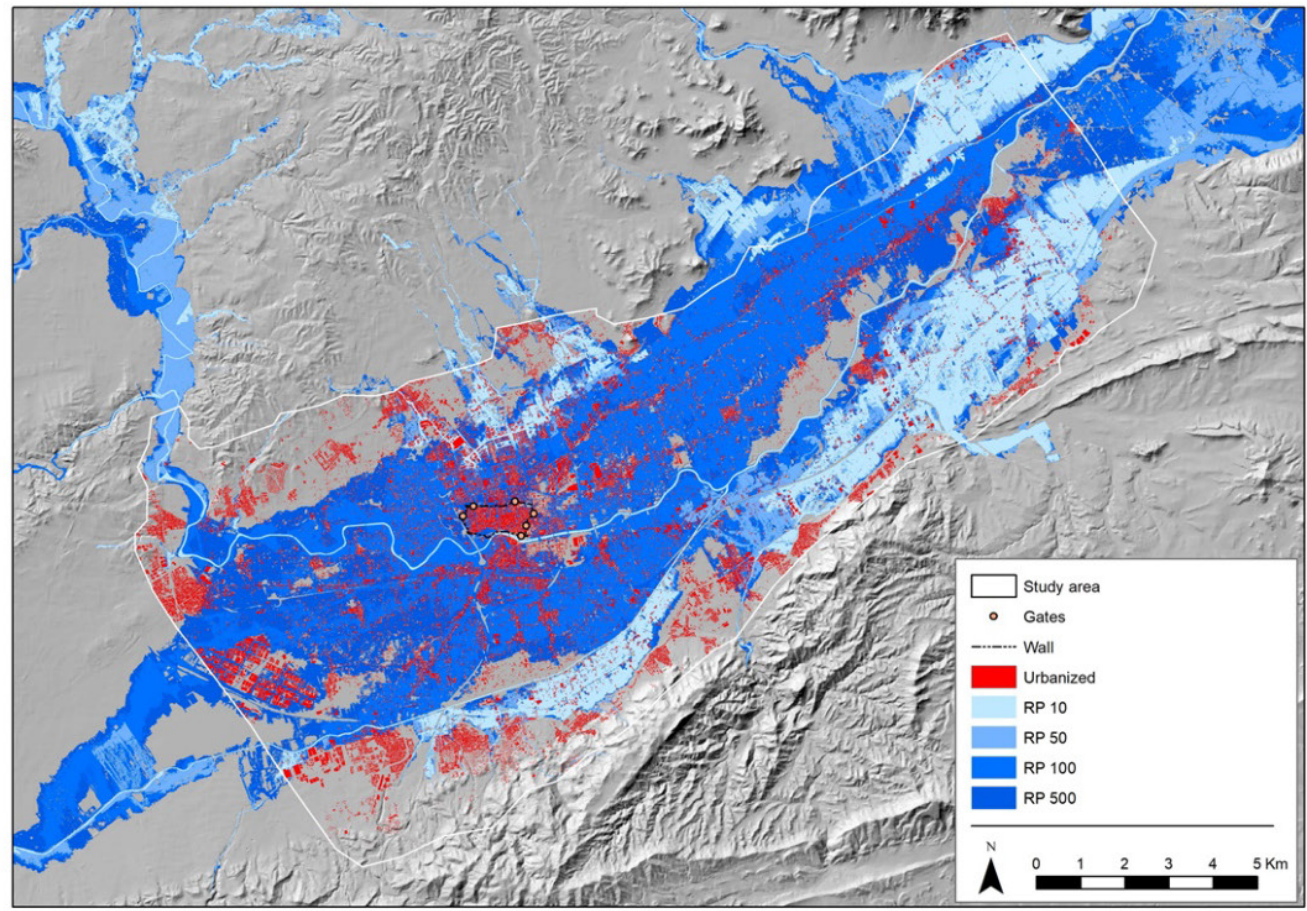

Figure 10. Evolution of flood risk over the last two centuries in the Huerta of Murcia. Source: The various return periods (RPs) have been obtained from MITECO (2020). The polygons are urban plots and have been obtained from Pablo del Villar's map of 1810 (MCU, 2020) for 1810 and from MH (2020) for 2019. 


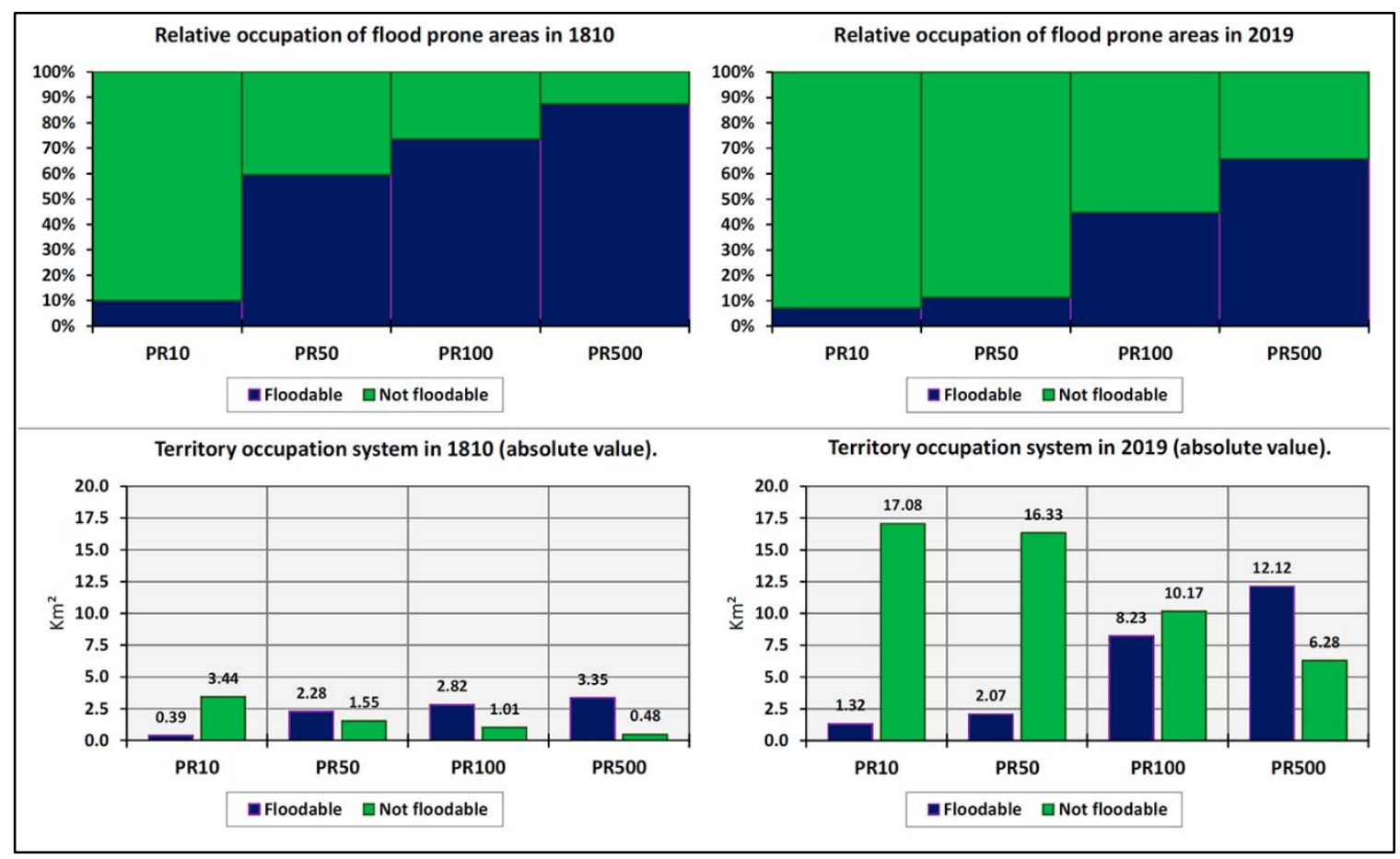

Figure 11. Evolution of flood risk over the last two centuries in the Huerta of Murcia. Source: The different return periods (RPs) have been obtained from MITECO (2020). The polygons in red are urban plots and have been obtained from Pablo del Villar's map of 1810 (MCU, 2020) for 1810 and from MH (2020) for 2019.

\section{Discussion and conclusions}

Hermeneutic analysis shows that, at least in the study area, the generalisation of a risk process is not a specific consequence of modernity, as indicated by Beck (2002). Giddens (2003) pointed out that the essential role of a welfare state is to mitigate risk for its inhabitants. However, the working classes were governed to further the interests of the oligarchy, and various subsectors of the oligarchy tried to win popular support and thus exercise power over the other governing classes, under the threat of using this power against them, but never to the extent of putting the system itself at risk.

Research on the analysis of vulnerability and risk in differing spaces and periods shows the difficulty of studies involving complex adaptive socio-ecological systems (Holland, 1995; Adger, 2006). Partiality the positioning of private interests over and above the resolution of general problems is the variable that makes it difficult to fully understand this process. Since society as a whole can behave in an adaptive manner in the face of situations of stress or change, but when solutions depend on a few individuals, we move out of the optimal eco-social terrain, and enter unpredictable personal and psychological terrain. Considering that society as a whole can behave adaptively in stress or change situations, if the solutions depend on few people this moves away from the ecosocial optimum terrain to enter in the unpredictable personal and psychological terrain.

It has been demonstrated that hermeneutic analysis is important to transcend the mere description of events that occur during a disaster and to highlight the problems and potentialities of each period in a historical key. Historical analysis of text shows the idiosyncrasies, potentialities, and weaknesses of each historical moment. These should be considered when planning new projects or scenarios of water use, since doing so enables the identification of inertias with respect to the most affected sectors, and this facilitates an extrapolation of the analysis to the present time to optimise planning.

The intensity of the event, the conditions of the population, the hydrological dynamics, and socio-political and economic conditions in the face of the risk of flooding explain the differences 
between centuries. The suddenness of floods means that immediate management is largely improvised, although improvements in this respect can be seen over the centuries. Changes begin to take place from the eighteenth century onwards thanks to improvements in infrastructure. Nevertheless, slowness in the implementation of solutions to problems leave the system in a precarious situation, so that, the effects of a flood are never surpassed definitively before another flood strikes. Throughout the entire period studied, the cause of the flooding was understood in a more or less scientific way. However, when it came to dealing with the difficulties, the appropriate measures were not taken because the managers of the territory were faced with a bureaucracy and level of poverty that slowed any actions. Throughout the study period, the most vulnerable people were often left out of decision-making because of their limited participation in power structures and poor access to resources. Public policies for intervention to reduce vulnerability must recognise the environmental characteristics and identify the inequalities and social implications of risk to create a framework for greater resilience.

Historical cartographic analysis has enabled a better understanding of internal flooding processes, as well as a better characterisation and contextualisation of the complexity of the study area. Thanks to the use of old maps, we have delimited a historical region such as the Huerta of Murcia. Due to its complexity and internal structures, that geographical space escapes a simple administrative delimitation. The use of old maps enables us to understand the spatial patterns of flooding for the Santa Teresa Flood and to relate these patterns to the local flood defence system. The entire protection system has been generated in a secular way to protect the city of Murcia from danger, at the cost of increasing the danger in nearby rural areas. The Reguerón Canal and the strategy of shortening the meanders in the River Segura are a good example in this respect. When asked if the flood adaptation strategy was more appropriate in the past than it is today, we can say that it was not. On the contrary, the population was more vulnerable to floods and was exposed to them in a less adapted way. Although it is true that there were complex systems of protection against floods - such as the medieval city wall. But this wall ceased to be useful centuries ago. After the Christian conquest of the Kingdom of Granada at the end of the fifteenth century, Murcia ceased to be a frontier territory and the wall gradually lost its defensive role. In fact, it was a brake on urban development, to the point that a municipal grain warehouse, built in 1629, was erected on part of the wall (Roselló Verger and Cano García, 1975). Therefore, the wall has not served against flooding for at least the last 400 years.

It is interesting to observe how the two most catastrophic floods in the city of Murcia (San Calixto and Santa Teresa) occurred when the wall was no longer functional. Perhaps its conservation would have substantially reduced the level of damage. If the wall were conserved today, it would protect the historic centre of the city of Murcia from the most severe floods. Finally, the most important fact that we have been able to highlight is that, despite the enormous absolute increase in exposure over the last two centuries, the type of exposure has improved substantially in relative terms. Even today there is less surface area exposed to RP50 than in 1810. This improvement in the system of adaptation is probably due to the implementation of legal controls of land use that limit exposure to flooding (PérezMorales et al., 2018). These changes have contributed to a reduction in institutional and political vulnerability (López-Martínez et al., 2017). With regard to the possible explanation as to why people were protected in a less efficient manner even though they were aware of the continuous danger of flooding, a hermeneutic analysis has enabled a better understanding of the contradictions faced by a preindustrial agrarian economy such as that of the Huerta of Murcia (Pérez Picazo et al., 1980).

A system based on irrigation needs to occupy a space where water can be easily transported despite the constant danger of flooding (Calvo García-Tornel, 1972). This unprecedented cartographic analysis, together with the analysis of historical texts, has made it possible to establish what we could call "the huertan farmer paradox". That is, a model of occupation of the territory that revolves around the following contradiction: greater exposure to the danger of flooding in order to prosper economically, which implies a high probability of suffering more floods that cause serious losses in the economy of the area. With great stoicism, the people in the Murcia countryside adapted to the fact that their lives could suddenly become impoverished and miserable. The lack of social demands made after the great 
floods (Pérez Picazo et al., 1980) may be explained by the fact that the people was aware of the danger, and so they only demanded short-term management strategies. Such a system is full of contradictions but remains, nevertheless, socially resilient and can be understood as the ability of society to internalise adversity and adapt to new realities.

\section{References}

Adger, W.N. 2006. Vulnerability. Global Environmental Change 16 (3), 268-281. https://doi.org/10.1016/j.gloenvcha.2006.02.006

Aguilera, J.B., Megías, R.J.P. 2014. Nuevos datos sobre la muralla medieval de Murcia; reflexiones sobre la cerca medieval en el siglo XIII. In P. Cressier, V. Salvatierra Cuenca (Coord.). Las Navas de Tolosa 12122012: miradas cruzadas, pp. 527-536.

Barredo, J.I. 2007. Major flood disasters in Europe: 1950-2005. Natural Hazards 42 (1), 125-148. https://doi.org/10.1007/s11069-006-9065-2

Barriendos, M., Gil-Guirado, S., Pino, D., Tuset, J., Pérez-Morales, A., Alberola, A., Costa, J., Balasch, J.C., Castelltort, X., Mazón, J., Ruiz-Bellet, J.L. 2019. Climatic and social factors behind the Spanish Mediterranean flood event chronologies from documentary sources (14th-20th centuries). Global and Planetary Change 182, 102997. https://doi.org/10.1016/j.gloplacha.2019.102997

Barriendos, M., Rodrigo, F.S. 2006. Study of historical flood events on Spanish rivers using documentary data. Hydrological Sciences Journal 51 (5), 765-783. https://doi.org/10.1623/hysj.51.5.765

Beck, U. 2002. La sociedad del riego global. Madrid.Siglo Veintiuno de España Editores, pp. 265, Madrid.

Biblioteca Digital Hispánica. 2020. Mapas antiguos. Biblioteca Nacional de España. http://www.bne.es/es/Colecciones/GeografiaMapas/Subcolecciones/map_antiguos.html

Blöschl, G., Kiss, A., Viglione, A., Barriendos, M., Böhm, O., Brázdil, R., Coeur, D., Demarée, G., Llasat, M.C., Macdonald, N., Retsö, D., Roald, L., Schmocker-Fackel, P., Amorim, I., Bělínová, M., Benito, G., Bertolin, C., Camuffo, D., Cornel, D., Doktor, R., Elleder, L., Enzi, S., Garcia, J.C., Glaser, R., Hall, J., Haslinger, K., Hofstätter, M., Komma, J., Limanówka, D., Lun, D., Panin, A., Parajka, J., Petrić, H., Rodrigo, F.S., Rohr, C., Schönbein, J., Schulte, L., Silva, L.P., Toonen, W.H.J., Valent, P., Waser, J., Wetter, O. 2020. Current European flood-rich period exceptional compared with past 500 years. Nature 583, 560-566. https://doi.org/10.1038/s41586-020-2478-3

Botrel, J.F. 2019. Paris-Murcie, París-Murcia, Murcia-París: la presse et la charité sans frontières, en France et en Espagne, en 1879. Çédille: Revista de Estudios Franceses 16, 101-114.

Brázdil, R., Demarée, G. R., Kiss, A., Dobrovolný, P., Chromá, K., Trnka, M., Dolák, L., Řezníčková, L., Zahradníček, P., Limanowka, D., Jourdain, S. 2019. The extreme drought of 1842 in Europe as described by both documentary data and instrumental measurements. Climate of the Past 15, 1861-1884. https://doi.org/10.5194/cp-15-1861-2019

Brázdil, R., Kiss, A., Luterbacher, J., Nash, D.J., Řezníčková, L. 2018. Documentary data and the study of past droughts: a global state of the art. Climate of the Past 14, 1915-1960. https://doi.org/10.5194/cp-14-19152018

Brooks, N., Adger, W.N., Kelly, P.M. 2005. The determinants of vulnerability and adaptive capacity at the national level and the implications for adaptation. Global Environmental Change 15, 151-163. https://doi.org/10.1016/j.gloenvcha.2004.12.006

Calvo García-Tornel, F. 1969. La huerta de Murcia y las avenidas del Guadalentín. Papeles de Geografía 1, 11137.

Calvo García-Tornel, F. 1972. La formación del paisaje agrario de la huerta de Murcia. Revista de Geografía 6, 533.

Calvo García-Tornel, F. 1997. Algunas cuestiones sobre Geografía de los riesgos. Scripta Nova, Revista Electrónica de Geografía y Ciencias Sociales 10, http://www.ub.edu/geocrit/sn-10.htm 
Calvo García-Tornel, F. 2001. Sociedades y territorios en riesgo. Ediciones del Serbal, pp. 186, Barcelona.

Cardona, O., Van Aalst, M. K., Birkmann, J., Fordham, M., McGregor, G., Perez, R., Pulwarty, R.S., Schipper, L.F. Sinh, B.T. 2012. Determinants of risk: Exposure and vulnerability. In: C. Field, V. Barros, T.F. Stocker, D. Qin (Eds.), Managing the risks of extreme events and disasters to advance climate change adaptation. A Special Report of Working Groups I and II of the Intergovernmental Panel on Climate Change (IPCC). Cambridge University Press, pp. 65-108, Cambridge, UK, and New York.

Cascales, F. 1621. Discursos históricos de la mui noble i mui leal ciudad de Murcia y su reino. Benedito, Murcia.

Colten, C. E. 1991. A historical perspective on industrial wastes and grondwater contamination. The Geographical Review 81 (2), 215-228.

Cutter, S., Finch, C. 2007. Temporal and spatial changes in social vulnerability to natural hazards. PNAS. 105 (7), 2301-2306. https://doi.org/10.1073/pnas.0710375105

Dauphiné, A. 2001. Risques et catastrophes. Observer, spatialiser, comprendre, gérer. Armand Colin. París.

Diaz Cassou, P. 1887. La huerta de Murcia, su topografía, geología, climatología; descripción de sus sistemas de riego y saneamiento y de cada uno de los cauces que constituyen dichos sistemas. Régimen general de la huerta de Murcia y especial de cada uno de sus heredamientos. Imp. de Fontanet. Madrid

Diez-Herrero, A. 2020. Primera aproximación al registro de avenidas e inundaciones históricas en la provincia de Segovia. En I. López Ortiz, J. Melgarejo Moreno (Eds.), Riesgo de inundación en España: análisis y soluciones para la generación de territorios resilientes. Universidad de Alicante, pp. 1211-1220, Alicante

Echegaray, J.D. 1851. Memoria sobre las causas de la sequía de las provincias de Almería y Murcia, y de los medios de atenuar sus efectos, escrita con arreglo al programa del real decreto de 30 de marzo de 1850. Imprenta del Ministerio de Comercio, Intrucción y Obras Públicas. Madrid.

Endfield, G.H. 2007. Archival explorations of climate variability and social vulnerability in colonial Mexico. Climatic Change 83 (1-2), 9-38. https://doi.org/10.1007/s10584-006-9125-3

Frey Sánchez, A.V. 2000. Las representaciones gráficas de la Ciudad de Murcia en la Edad Media. Imafronte 15, 43-70.

García Antón, J. 1993. Las murallas medievales de Murcia. Murcia, Universidad de Murcia-Real Academia Alfonso X el Sabio, Murcia

Giddens, A. 2003. Un mundo desbocado. Ed. Taurus. Madrid

Gil-Guirado, S. 2017. Deconstruyendo riesgos. Cuatro siglos de cambios en la vulnerabilidad y adaptación a las inundaciones y sequías en Murcia. Revista de Historia Moderna. Anales de la Universidad de Alicante 35, 308-344.

Gil-Guirado, S., Pérez-Morales, A. 2019. Variabilidad climática y patrones termopluviométricos en Murcia (18632017): Técnicas de análisis climático en un contexto de cambio global. Investigaciones Geográficas 71, 27-54.

Gil-Guirado, S., Espín-Sánchez, J.A., Prieto, M.R. 2016. Can we learn from the past? Four hundred years of changes in adaptation to floods and droughts. Measuring the vulnerability in two Hispanic cities. Climatic Change 139 (2), 183-200. https://doi.org/10.1007/s10584-016-1768-0

Gil-Guirado, S., Gómez-Navarro, J.J., Montávez, J.P. 2019. The weather behind words-new methodologies for integrated hydrometeorological reconstruction through documentary sources. Climate of the Past 15 (4), 1303-1325. https://doi.org/10.5194/cp-15-1303-2019

Glaser, R. Kahle, M. 2020. Reconstructions of droughts in Germany since 1500 - combining hermeneutic information and instrumental records in historical and modern perspectives. Climate of the Past 16, 12071222. https://doi.org/10.5194/cp-16-1207-2020.

Glaser, R., Riemann, D., Schönbein, J., Barriendos, M., Brázdil, R., Bertolin, C., Camuffo, D., Deutsch, M., Dobrovolný, P., van Engelen, A., Enzi, S., Halíčková, M., Koenig, S. J., Kotyza, O., Limanówka, D., Macková, J., Sghedoni, M., Martin, B., Himmelsbach, I. 2010. The variability of European floods since AD 1500. Climatic Change 101 (1-2), 235-256. https://doi.org/10.1007/s10584-010-9816-7 
Glaser, R., Himmelsbach, I., Bösmeier, A. 2017. Climate of migration? How climate triggered migration from southwest Germany to North America during the 19th century. Climate of the Past 13, 1573-1592. https://doi.org/10.5194/cp-13-1573-2017

Grinsted, A., Moore, J.C., Jevrejeva, S. 2012. Homogeneous record of Atlantic hurricane surge threat since 1923 . PNAS 109 (48), 19601-19605. https://doi.org/10.1073/pnas.1209542109

Hernández, A. 1885. Inundaciones de la huerta de Murcia. Juicio sobre su frecuente repetición de pocos años a esta parte; sus terribles desastres, sus causas y remedios. Imprenta «El Diario». Murcia.

Holland, J. 1995. Hidden Order: How Adaptation Builds Complexity. MA. Addison-Wesley, Reading.

Horacio, J., Ollero, A., Noguera, I.,Fernández-Pasquier, V. 2019. Flooding, channel dynamics and transverse infrastructure: a challenge for Middle Ebro river management. Journal of Maps 15 (2), 310-319. https://doi.org/10.1080/17445647.2019.1592719

IGN (Instituto Geográfico Nacional). 2020. Plan Nacional de Ortofotografía Aérea (PNOA). Retrieved June 2020, from: https://pnoa.ign.es/

IGME (Instituto Geológico y Minero de España). 2020. Mapa Geomorfológico de España a escala 1:50.000. Retrieved January 2020, from: https://www.igme.es/

Lillo Carpio, M. 2000. La huerta de Murcia como ejemplo de escorrentía derivada inscrita en llanura de crecida. Papeles de Geografía 32, 61-75.

López-Martínez, F., Gil-Guirado, S., Pérez-Morales, A. 2017. Who can you trust? Implications of institutional vulnerability in flood exposure along the Spanish Mediterranean coast. Environmental Science and Policy 76, 29-39. https://doi.org/10.1016/j.envsci.2017.06.004

MITECO (Ministerio para la Transformación Ecológica y el Reto Demográfico). 2020. Sistema Nacional de Cartografía de Zonas Inundables. Retrieved July 7 2020, from: https://www.miteco.gob.es/es/agua/temas/gestion-de-los-riesgos-de-inundacion/snczi/

Marset Campos, P., Chacón Jímenez, F., Lemeunier, G., Ramps García, E., Saturno Hernandez, P.J., Valera Candel, M.F. 1981. La sociedad murciana y cartagenera y las epidemias durante los siglos XVII, XVIII y XIX. In: VV.AA. De Historia Médica Murciana. II Las epidemias. Academia Alfonso XX El Sabio, pp. 209-248), Murcia.

MCU (Ministerio de Cultura y Deportes). 2020. Cartografía de la Guerra de la Independencia. Retrieved July 20 2020, from: https://bvpb.mcu.es/es/inicio/inicio.do

Messerli, B., Grosjean, M., Hofer, T., Nunez, L., Pfister, C. 2000. From nature-dominated to human-dominated environmental changes. Quaternary Science Reviews 19 (1-5), 459-479. https://doi.org/10.1016/S02773791(99)00075-X

MH (Ministerio de Hacienda). 2020. Sede Electrónica del Catastro. Retrieved June 12 2020, from: http://www.catastro.meh.es/esp/sede.asp

Montes Bernárdez, R. 2002. Las murallas de Murcia en el siglo XIX. Reconstrucción y destrucción. Murgetana 106, 95-101.

Nash, D.J., Klein, J., Endfield, G.H., Pribyl, K., Adamson, G.C., Grab, S.W. 2019. Narratives of nineteenth century drought in southern Africa in different historical source types. Climatic Change 152 (3-4), 467-485. https://doi.org/10.1007/s10584-018-2352-6

Navarro Santa-Cruz, E., Robles Fernández A. 2002. EL Tramo occidental de la muralla islámica murciana, junto a la Puerta del Azoque. Memoria de la supervisión arqueológica realizada en los solares $\mathrm{n}^{\circ} 56$ de la C/ Sagasta y 37 de la C/ San Nicolás. Memorias de Arqueología 11, 449-468

O’Brien, M., Holland, T. 1992. The role of adaptation in archeological explanation. American Antiquity $n^{\circ}$ 57, 3669. https://doi.org/10.2307/2694834

Olcina Cantos, J. 2008. Cambios en la consideración territorial, conceptual y de método de los riesgos naturales. Scripta Nova. Revista Electrónica de Geografía y Ciencias Sociales, vol. XII, 270 (24). http://www.ub.es/geocrit/sn/sn-270/sn-270-24.htm 
Olcina Cantos, J., Díez-Herrero, A. 2017. Cartografía de inundaciones en España. Estudios Geográficos 78 (282), 283-315.

Ollero, A. 2020. Crecidas, inundaciones y resiliencia: restauración fluvial contra los falsos mitos. En I. López Ortiz, J. Melgarejo Moreno (Eds.). Riesgo de inundación en España: análisis y soluciones para la generación de territorios resilientes Alicante. Universidad de Alicante, pp. 549-568, Alicante.

Pérez Picazo, M.T., Lemeunier, G., Chacón, F. 1980. Materiales para una historia de Murcia en los tiempos modernos. Universidad de Murcia. Murcia.

Pérez-Morales, A., Gil-Guirado, S., Olcina Cantos, J. 2018. Housing bubbles and the increase of flood exposure. Failures in flood risk management on the Spanish south-eastern coast (1975-2013). Journal of Flood Risk Management 11, S302-S313. https://doi.org/10.1111/jfr3.12207

Pfister, C. 2011. "The Monster Swallows You". Disaster Memory and Risk Culture in Western Europe, 15002000. RCC Perspectives 1, 1-23.

Pita, M.F., Olcina Cantos, J. 2000. Riesgos naturales, disciplina geográfica de futuro. Prólogo de número monográfico riesgos naturales. Boletín de la AGE 30, 3-8.

Prieto, M.R., García Herrera, R. 2009. Documentary sources from South America: Potential for climate reconstruction. Palaeogeography, Palaeoclimatology, Palaeoecology 281 (3-4), 196-209. https://doi.org/10.1016/j.palaeo.2008.07.026

Prieto, M.R., Rojas, F. 2012. Documentary evidence for changing climatic and anthropogenic influences on the Bermejo Wetland in Mendoza, Argentina, during the 16th-20th century. Climate of the Past 8, 951-961. https://doi.org/10.5194/cp-8-951-2012

Prieto, M.R., Rojas, F. 2015. Determination of droughts and high floods of the Bermejo River (Argentina) based on documentary evidence (17th to 20th century). Journal of Hydrology 529, 676-683. https://doi.org/10.1016/j.jhydrol.2015.06.035

Rashid, H. 2011. Interpreting flood disasters and flood hazard perceptions from newspaper discourse: Tale of two floods in the Red River valley, Manitoba, Canada. Applied Geography 31 (1), 35-45. https://doi.org/10.1016/j.apgeog.2010.03.010

Rico Sinobas, M. 1851. Memoria sobre las causas meteorológico-físicas que producen las constantes sequías de Murcia y Almería. Ministerio de Comercio, Madrid.

Roselló Verger, V., Cano García, G.M. 1975. Evolución urbana de la ciudad de Murcia (831-1973). Ayuntamiento de Murcia, Murcia.

Smit, B., Wandel, J. 2006. Adaptation, adaptive capacity and vulnerability. Global Environmental Change 16 (3), 282-292. https://doi.org/10.1016/j.gloenvcha.2006.03.008

Torres Fontes, J., Calvo García-Tornel, F. 1975. Inundaciones en Murcia (siglo XV). Papeles de Geografía 6, 2949.

Villevieille, A. (coord.). 1997. Les risques naturels en Méditerranée. Situation et perspectives. Les Fascicules du Plan Bleu. París. 


\section{Annex A}

\section{Main text in historical documents on the flood of San Calixto in 1651}

Doc. 1: Murcia on Thursday, October 19, 1651 (MCB of 1651. MMA): "Que por cuanto por la inundación de la avenida grande del río de Segura el sábado 14 por la mañana que fue con tanta furia que cogiendo a esta ciudad descuidados sin ser posible prevenir el remedio como con tanta furia que ha roto el azud luego por otra parte dejando su término ordinario y toda la huerta arramblada, llevándose los frutos sembrados, ganados mayores y menores, derribando torres, barracas, casas y barrios enteros y los conventos de religiosos de San Agustín y Religiosas Capuchinos [...] y después de esto se ha roto el malecón y caído la pared del río desde la puerta del Convento de San Francisco que son las principales defensas que esta ciudad tenía para las avenidas del Río y cada día con la mucha agua que entró en las casas y abrió los cimientos, se van cayendo y han muerto muchas personas por cuya causa la mayor parte de los pocos vecinos que había se salen y se van a diferentes partes por conservar sus vidas. Los reparos de estos edificios y roturas requieren pronto remedio por ser para la conservación de esta ciudad y por hallarse sin fuerzas ni caudal para poderlos hacer ni efectivo de sus propios de que valerse por estar extenuados y con muchos embargos por diferentes acreedores que hay a ellos por diferentes créditos [...]. Por lo tanto, acuerda la ciudad se dé cuenta a su majestad del miserable estado en que se halla esta ciudad con el dicho suceso, suplicándole sea servido de enviar persona que vea los dichos daños y trate de su remedio socorriendo a esta ciudad para las dichas necesidades con la cantidad que fuera servido, como lo espera de su grandeza".

Doc. 2: Murcia on December 26, 1651 (MCB of 1651. MMA): "en el estado en que se halla esta ciudad con los daños que ha recibido con la peste que se padeció el años de 1648, con que murieron más de 60.000 personas y la plaga de langosta, falta de frutos, quema general de la hoja para la cría de la seda y con la inundación del río de Segura que sucedió en 14 de octubre que fue tan grande [...] y por haber roto el río el azud de donde toman las acequias agua para regar la huerta y por diferentes partes habiendo dejado su curso ordinario y los vecinos que había viendo el riesgo en que tienen expuestas sus vidas que con media crecida del río por haberse roto el paredón de argamasa en que se batían las aguas desde la puente hasta el convento de San Francisco se han ido y ausentado a otras poblaciones de suerte que su vecindad no es hoy de 50 vecinos y cada día se va minorando con la falta de trigo y necesidad que se padece de todo lo cual esta ciudad tiene puesto en consideración a su majestad suplicándole sea servido de mandar se haga una rebaja considerable en el precio de cabezón de Alcabalas".

Doc. 3: Murcia on February 10, 1652 (MCB of 1652. MMA): "que se baje el santísimo Sacramento de la Torre donde esta desde la inundación del río [...] y misa solemne de gracias a su divina majestad por habernos librado del riesgo tan grande de la inundación".

Doc. 4: Murcia on June 21, 1653 (MCB of 1653. MMA): "que por cuanto el río de Segura viene creciendo y por la poca firmeza que tiene la presa estacada del azud respecto de no haberse podido acabar".

Doc. 5: Murcia on November 8, 1650 (MCB of 1650. MMA): "el sobreacequiero en que da cuenta de algunos daños que necesitan arreglar en el río y partido de esta ciudad [...] para la seguridad del río cuando puede tener riesgo esta ciudad"

Doc. 6: Murcia on September 5, 1651 (MCB of 1651. MMA): "se limpia el val de lluvia para prevenir la época de lluvias y avenidas del río".

Doc. 7: Murcia on October 19, 1651 (MCB of 1651. MMA): "la mayor parte de los pocos vecinos que había se salen y se van a diferentes partes por conservar sus vidas y los reparos destos edificios y roturas requieren pronto remedio por ser para la conservación de esta ciudad y por hallarse sin fuerzas ni caudal para poderlos hacer ni efectivo de sus propios de que valerse por estar extenuados y con muchos embargos por diferentes acreedores [...] acuerda la ciudad se dé cuenta a su magestad del miserable estado en que se halla esta ciudad con el dicho suceso suplicandole sea servido de enviar persona que vea los dichos daños y trate de su remedio socorriendo a esta ciudad para las dichas necesidades con la cantidad que fuera servido, como lo espera de su grandeza". 
Doc. 8: Murcia on November 11, 1651 (MCB of 1651. MMA): "los capitanes de las parroquias han alistado la gente de sus compañías para que vayan los días que les tocare al dicho reparo o por sus criados a jornal por su cuenta y porque por ser beneficio común y obra pública toca que generalmente a todas sin ninguna excepción pues no hay privilegio para librarse de los riesgos y daños de la inundación que en esta ocasión la han padecido los santuarios y las religiosas más recogidas y porque se ha entendido que en algunas personas a causado escrúpulo el trabajar, por si o contribuyendo para el dicho reparo por decir que tocaba a los buenos hombres llanos y no a los caballeros hijosdalgo y porque esto se ejecutaba así cuando el dique estaba entero y sin ninguna brecha solo para reforzarlo y subirlo y ahora milita diferente razón pues roto por tantas partes con la menor crecida se inundará y destruirá esta ciudad y para este reparo no puede haber accidente que lo embarace [...] y en consideración de destas razones y por la imposibilidad en que esta la ciudad el señor obispo de Cartagena y los señores dean y cabildo y todo el estado eclesiástico debe ayudar a obra tan justa y en que tienen tanta parte y parece que lo harán con gusto pues no se puede esperar menos de sus muchas obligaciones y de sus piadosas atenciones".

Doc. 9: Murcia on February 12, 1652 (MCB of 1652. MMA): "se había de hacer en procesión y misa con sermón en hacimiento de gracias de habernos librado de tan gran peligro, que el cabildo convidaba a la ciudad por si tenía a gusto de asistir y la ciudad con toda estimación aceptó [...] Don Diego Riquelme canónigo de la dicha Santa Iglesia y en el sermón dijo que los castigos que dios Nuestro Señor enviaba a esta ciudad era por el poco respeto que se tenía a los sacerdotes, la poca atención con el señor obispo, que contra su voluntad y en su ofensa había visitado sus graneros habiendo asistido por sus sacerdotes en la inundación con el agua a los pechos repartiendo limosna de pan generalmente cuando los gobernadores y particulares estaban retirados en sus comodidades sin padecer ninguno; que la ciudad no cumplía sus votos y que los que eran de parecer que no asistiesen en la dicha Santa Iglesia eran demonios y otras cosas en ofensa de la ciudad hablándole cara a cara [...] habló ocasionando alborotos en desorden de su ilustre autoridad, causando con sus predicaciones escándalo notable y murmuración siendo cierto que la ciudad y los caballeros que la componen con la mayor atención como se debe creer de sus empleos y obligaciones han hecho y hacen la estimación que se debe [...] y que la visita que se hizo de los graneros del Señor Obispo no fue por acuerdo de la ciudad ni tubo ninguna inteligencia y cuando los caballeros capitulares que asistían lo entendieron que fue con publicidad y por dar satisfacción al pueblo que padecía necesidad con la falta grande que había de trigo hasta conocer el que el Señor Obispo tenía con la mayor cortesía que se pudo y sin ninguna inquietud, fuerza ni escándalo como consta por papeles [...] y que muchos caballeros regidores arriesgando sus vidas solicitaron el remedio de las necesidades públicas en la inundación incesantemente y las socorrieron dando para ello el trigo que tenían para el sustento de sus familia y haciendo las limosnas que podían y el señor obispo y el cabildo eclesiástico habiendo sucedido la inundación el sábado 14 de octubre no empezaron a hacer limosna de pan hasta el miércoles siguiente". 


\section{Annex B}

\section{Main text in historical documents on the flood of Nuestra Señora de los Reyes in 1733}

Doc. 1: Murcia on August 11, 1733 (MCB of 1733. MMA): "que la Contraparada del Río Segura que refrena las aguas para el riego de esta huerta, necesita de algunos reparos prontos para su conservación".

Doc. 2: Murcia on February 6, 1733 (MCB of 1733. MMA): "obras para dar salida a las aguas del Río Sangonera arregladas al mapa y Proyecto de Don Pedro Thomas a la que se han opuesto en el Real Consejo los Señores Conde del Valle San Juan; el de Montealegre y otros interesados en esta huerta".

Doc. 3: Murcia on September 6, 1733 (MCB of 1733. MMA): "riesgo en que se halló la población con la avenida del río: la ciudad teniendo presente que la crecida ha sido tan inopinada y soberbia que se mantiene creciendo hallándose tan elevada que a derramado en lo general de la huerta y sin servirle este desahogo continua tomando agua y amenazando total ruina a esta población, mayormente por los sitios del malecón, puerta de San Francisco de del Puente de Madera, la que nombran de Orihuela y otros, por la debilidad y flaqueza de sus terrenos y empezado a derramar por algunos de ellos con general clamor lo que ha precisado al Señor Corregidor y distintos Caballeros Capitulares con botar varias tropas de vecinos y ocurrir a precaver dichos sitios reforzándolos con fajinas, tablachos y estacadas a fin de evitar el riesgo en que se halla esta población; debiéndose recelar con mayor fundamente a vista del temporal que continua sin ceder la creciente del río y que en concurso de los trabajadores con la continuación del afán y su miseria, necesitan reforzar sus fuerzas con el preciso alimento y quedar satisfechos al mismo tiempo los materiales de madera, paja, soga y otros [...] considerando la ciudad que la incesante lluvia general y continuación de la crecida puede ocasionar mayores recelos la noche de este día con la inundación, deseando vigilar sobre el remedio con el resto de sus fuerzas y la asistencia de mayor número de caballeros capitulares, acordó se forme escala para esta concurrencia".

Doc. 4: Murcia on September 10, 1733 (MCB of 1733. MMA): "tratar de conferir y resolver el medio de reparar los innumerables daños que ha ocasionado la crecida del río Segura que sobrevino el 6 del corriente [...] entre los muchos estragos que a causado ha sido uno de los de mayor consideración haber quebrantado el trenque del Chillerón en el río de Sangonera [...] como también la nueva fortificación del principalísimo edificio del malecón, cuyos quebrantos ha hecho patentes la elevación la elevación de las aguas en aquel sitio manifestando lo mismo en las murallas del arenal hasta el puente de madera el que ha quedado intransitable debiéndose ocurrir con la misma vigilancia al terraplén del camino de la puerta de Orihuela, quijeros del río Viejo que ha destruido en su entrada se le da trascendencia el celo de esta ciudad a providencias el reparo de la acequia mayor de Aljufia que ha quebrado por distintas partes [...] la ciudad habiéndolo oído con las demás particulares noticias que han expuesto en su lugar cada uno de los caballeros que componen este consistorio dignas de la mayor atención por la evidencia de los innumerables daños que se han seguido: pueda con el dolor que corresponde a este impensado accidente, el que ha lastimado la mayor parte del vecindario; de esta huerta llevándoles los esquilmos pendientes de panizo, vino, frutas y hortalizas, linos y otros, destruyendo los palacios y demás habitaciones, sacando de ellos con voracidad el trigo, cebada, paja y demás prevenciones reservadas para su alimento y el de sus averíos ahogándose parte de ellos y otros [...] reabriendo las acequias, brazales, regaderas y escorredores, arruinando los puentes, maltratando los caminos, sendas y veredas, dejando muchas tierras sin uso y por consiguiente infructuosas; siendo tan furioso el ímpetu de la avenida que además de haber quebrado la acequia mayor de Aljufia uno de los vasos que dan riego a la mitad de la huerta le ha dejado a la de las Barreras luego con el depósito de tarquín imposibilitando el curso del agua para el beneficio de las tierras; ha levantado con tenacidad muchos morerales y barracas que patentemente se vieron venir por sobre las corrientes siendo estas tan eficaces en sus elevaciones que se empezaron a introducir por distintas partes de esta población, no obstante las prontas providencias que se aplicaron para contener con fajinas y estacadas este último golpe: siendo el más doloroso para esta ciudad lo extremado de sus propios y rentas y los ningunos caudales para poder acudir a contener y reparar tanto riesgo a que se halla expuesta esta capital si sobreviniere otra avenida, que se debe temer por lo inmediato del invierno; hallándose sus vecinos sus vecinos constituidos en la última miseria por las repetidas faltas de cosechas a que se les ha agregado esto impensado quebranto, sin quedarle arbitrio para subsanar por medio alguno el reparo de estos perjuicios ni más consuelo en tan continuados daños, que el de exponerlos a los reales pies de su majestad para que atendidos de su real clemencia se sirva conceder a esta ciudad los alivios proporcionados a tanta fatiga". 
Doc. 5: Murcia on September 12, 1733 (MCB of 1733. MMA): "misa solemne por habernos librado Dios de la inundación".

Doc. 6: Murcia on September 30, 1733 (МСB of 1733. MMA): "todos los vecinos pongan luces en sus casa la noche de este día y que los caballeros comisarios de los puestos del río, los ocupan luego con los oficiales de las compañías de parroquias y demás gente que fuese necesaria para los trabajos que ocurran en las fajinas y demás que se pueda ofrecer a preservar esta población de cualquiera inundación y que los maestros albañiles carpinteros, sus oficiales y peones acudan luego a las casa de su señoría con legones, azadas y demás herramientas para distribuirles las ordenes convenientes". 


\section{Annex C}

\section{Main text in historical documents on the flood of Santa Teresa in 1879}

Doc. 1: Murcia on October 15, 1879 (EI Diario de Murcia. MMA): "Día de luto, sí, día de luto para Muria el día de hoy. En esta noche pasada, la avenida más terrible del rio que se ha conocido, ha destrozado con sus negras, mugientes, y pestíferas olas, inmensas riquezas, $y$, ¡Dios sabe!, las víctimas que abra, causado. No es posible, a la hora que escribimos, calcular las desgracias que habrán ocurrido en la huerta; pero ahora cuando la ciudad está inundada, toda el agua hace retemijiar el Puente; cuando esta mas alto el nivel del rio que piso el del Arenal, ¿cómo estará la huerta? ¿Cuántos infelices habrán perecido, sin socorro? Desgraciadamente deben ser muchos [...]

Doc. 2: Murcia on October 18, 1879 (EI Diario de Murcia in MMA): "Nos hemos salvado murcianos, España ha oído nuestra voz y nos socorre [...] la Gaceta de Madrid publica un decreto abriendo una subscripción Nacional para socorrer a Murcia" [...] "las pérdidas de la huerta de Murcia, bien calculadas, en casas destruidas, animales muertos, aperos de labranza perdidos, tierras que hay que roturar, esquilmos, frutos, muebles, caminos que hay que abrir, acequias que hay que renovar, vías y caminos que levantar, tierras que sanear y lo que en este momento no se nos ocurre, ¡Oh, España!, no baja de 150.000 millones" (150.000 millones de pesetas, la moneda de la época, sería una cantidad aproximada de 900 millones de euros).

Doc. 3: Murcia on October 18, 1879 (EI Diario de Murcia in MMA): "Las pérdidas materiales consideradas para la huerta de Murcia, según cálculos aproximados, es de 200 millones, si bien esta cifra aumentaría el doble si los sedimentos arrastrados por las aguas y depositados en los bancales son de malas condiciones en cuyo caso secarán el arbolado".

Doc. 3: Murcia on October 24, 1879 (EI Diario de Murcia in MMA): "una de las obras que más podrían contribuir a evitar que las grandes masas de agua que se forman por las lluvias torrenciales en los montes de la provincia de Murcia, es la construcción del proyectado canal de Cieza, que recogerá las aguas desbordadas, fertilizando con ellas terrenos hoy casi incultos".

Doc. 4: Murcia on October 25, 1879 (EI Diario de Murcia in MMA): "Lo que se llama la "cuestión social" se presenta en Murcia en toda su pavorosa trascendencia. Hay en la huera millares de jornaleros sin pan y sin trabajo, hay millares de familias sin hogares [...] nadie cree que tiene el deber de tener hambre, nadie quiere resignarse a dormir a la intemperie y en el suelo húmedo, nadie se aviene a ir desnudo. He aquí la cuestión social: especie de gangrena de las modernas sociedades que se presenta en todas las desgracias de los pueblos. Y gracias que el colono de nuestra huerta no está estimulado por los incentivos que tiene el obrero de los grandes centros fabriles, o de las grandes capitales. Nuestro huertano es sobrio y morigerado hasta lo increíble; con un pedazo de pan y unas legumbres trabaja todo el día; con un poco de esparto se calza; con un poco de lienzo se viste, y con una inmensa fe en Dios y en la Virgen se alegra su corazón y vive los días plácidos y venturosos de las faenas agrícolas, con la sencillez de los antiguos patriarcas. Pero, a pesar de esto, decimos que está planteada la cuestión social, la cual hay que atender de modo que las medidas que se adopten no dejen rastro alguno en la población de la huerta. Cuanto antes, hay que suprimir el rancho, e inmediatamente que sea posible suspender el reparto del pan. El pan y el rancho no pueden dejar de ser una limosna, que si al principio se recibe con vergüenza, se regatea después, y se concluye totalmente por exigirse con descaro. Urge pues socorrer con trabajo, que es el socorro más noble, el que dignifica al hombre (librándole de la vagancia é impidiendo que se disipen en su corazón las nociones del bien y los sentimientos religiosos). A esa junta suprema de esta ciudad, compuesta de casi todas las corporaciones y autoridades, toca acelerar los momentos de resolución de esta suprema crisis, para que el mas enrome de la inundación no sea semillero de nuevos y mayores males".

Doc. 5: Murcia on October 28, 1879 (EI Diario de Murcia in MMA): "A Los pobres: no murmuréis. Todos los socorros son para vosotros y vosotros los recibiréis. Nadie os quitará nada: tened paciencia [...] si no tenéis paciencia y resignación los pobres, no seréis dignos de caridad. Cuando por amor de Dios se da una limosna, se quiere dar a los buenos, no a los viciosos, no a los que no han perdido nada, porque ya lo tenían todo perdido".

Doc. 6: Murcia on April 10, 1880 (El Diario de Murcia in MMA): "A quienes nos escriben anónimos: No sabemos ni podemos figurarnos quiénes son estos. Algunos nos parecen amigos, otros no lo parecen. Los más nos 
exigen que escribamos en EL DIARIO con arreglo al criterio suyo. Unos nos llaman volterianos é incrédulos, otros teocráticos y amigos de los curas. Unos nos excitan que combatamos al alcalde, al ayuntamiento, y otras autoridades; otros nos rechazan las palabras de elogio que tenemos para el gobernador".

Doc. 7: Murcia on December 7, 1879 (EI Diario de Murcia in MMA): "Lo justo sería, en la distribución de los donativos, indemnizar todos los perjudicados que ha habido, en la proporción que fuera posible. Para esto no debe haber clases, ni distinción, entre propietarios y jornaleros" [...] "hemos llamado la atención de la juntas sobre la propiedad urbana, pues estos propietarios se ven reducidos a una miseria vergonzante, más difícil de conllevar que la pobreza resignada y conocida" [...] "Respecto de las habitaciones de la huerta, creemos que el problema de su propiedad no debe ser obstáculo para su construcción; porque lo cierto y verdad es, que sean palacios, que sean barracas, que sean chozas, la población rural de la huerta viene disfrutando de generación en generación todos los albergues. Las casas o barracas deben hacerse donde estaban; allí sirven las tierras, allí albergan cómodamente los labradores, allí han de disfrutarlas siempre. Así como la inundación no preguntó de quien era para destruirlas, así la caridad no ha de preguntar de quien son para levantarlas. Por otra parte, la propiedad de la huerta está tan dividida y subdividida, que para cien propietarios ricos acaudalados que haya, hay diez mil pobres, que obtienen una mezquina renta de la tierra".

Doc. 8: Murcia on January 7, 1880 (EI Diario de Murcia in MMA): "En la zona inundada hay más de 50.000 personas, y de ellas 30.000 afligidos [...] Luego vamos a dar hogar al desvalido, para lo cual esta Junta construirá 200 casas y 200 barracas, e indemnizará la construcción de 2.000 más [...]. En la vega de Murcia las casas destruidas ascienden a 2.611 y las barracas a 314, las deterioradas a 423 y 1.047 respectivamente [...]. Los perjuicios que han sufrido las tierras inundadas ascienden a 591.622 pesetas, que con 2.753 .000 , valor de las viviendas y otros daños, forma un total de más de 8 millones de pesetas".

Doc. 9: Carta que en el diario el Semanario, dirige el diputado nacional y general Manuel Cassola a otro diputado (EI Semanario in MMA): "Mi querido General, los huertanos de este hermoso y desventurado país, tienen ya, los más desvalidos, trabajo que ejecutar, donde poder ganar el pan nuestro de cada día; todos ellos se encuentran vestidos, no obstante, pequeñas lagunas, casi como el día antes de la inundación. Muchos tienen sus viviendas levantadas, a otros se les están levantando, y a los demás se les levantaran en un término breve, según todas las probabilidades. El agua para el riego corre por las acequias, y los escorredores y azarbes mondados sanean el terreno y eviten la corrupción de la atmósfera respirable. La salud es buena, y la cosecha de la seda, con que comienza las labores del año nuestro inteligente y bravo huertano, ha comenzado ya con las halagüeñas esperanzas de siempre, esperanzas que endulzan los pasados sinsabores, alientan en el presente trabajo, $y$ predisponen para el porvenir. Solo le falta una cosa para creerse y considerarse regenerado: lo sangre de toda industria; el capital circulante, dinero. Pero ¿es que carece de él verdaderamente o que no se lo quieran dar?-No me toca responder a esta pregunta, la competencia de la respuesta es de ustedes, de la Ilustre Junta de Señores Diputados y Senadores, que reside en Madrid. -Yo espero confiado la siguiente contestación, que salva por completo a mi país: «lo tiene y se lo va inmediatamente repartir»". 